\title{
The United States Commission of Fish and Fisheries
}

And Its Exhibit at the Lourisiana

Purchase Exposition,

$$
\begin{gathered}
\text { St. Louis, Mo., } \\
1904 .
\end{gathered}
$$

$$
\text { W. de C. RAVENEL, }
$$

Representative on U. S. Government Board. 

H 343

U6 $\$ 4$

opy 1 


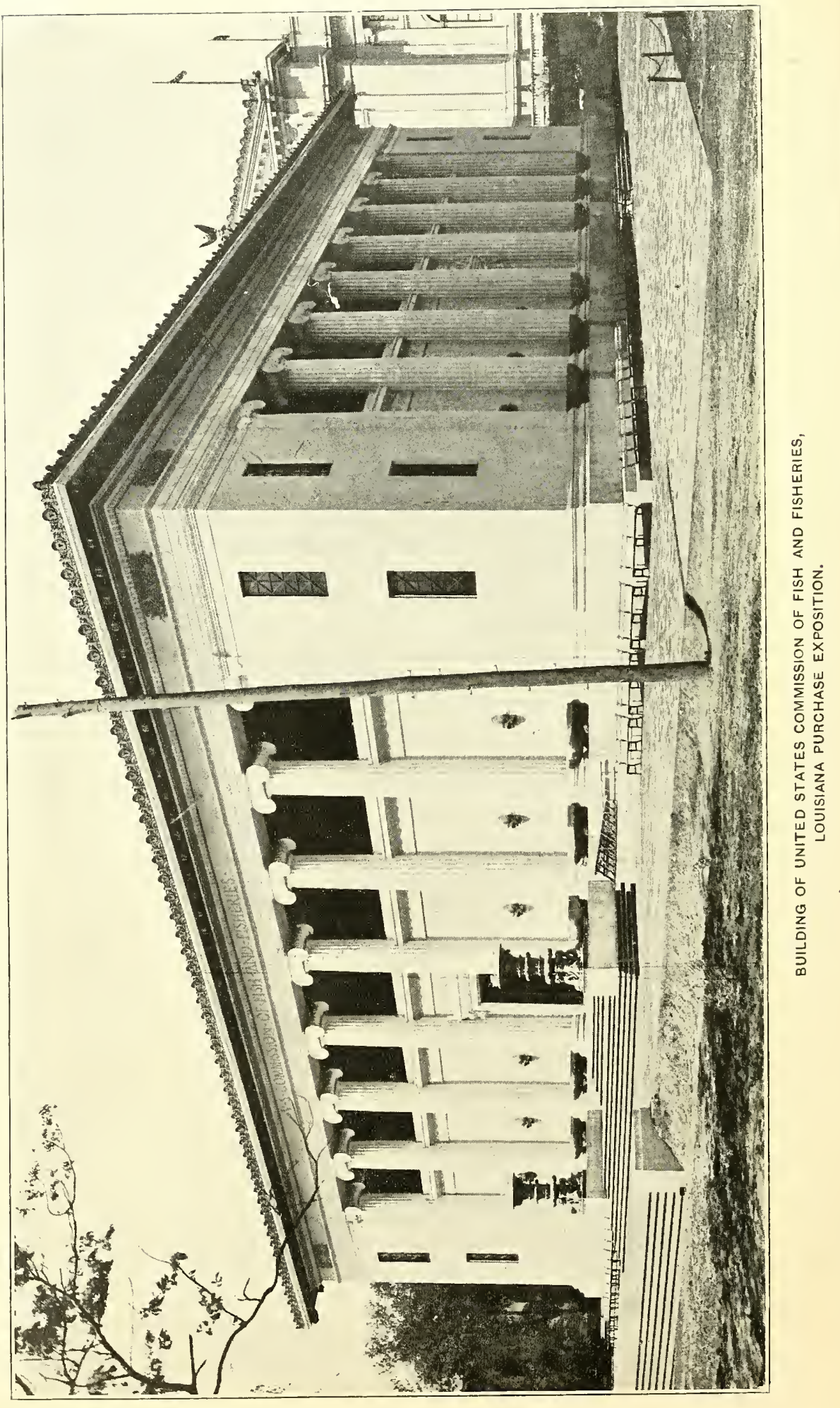




\title{
The United States Commission of Fish and Fisheries
}

\author{
And Its Exhibit at the Louisiana \\ Purchase Exposition, \\ St. Louis, Mo., \\ 1904.
}

\author{
W. de C. RAVENEL, \\ Representative on U. S. Government Board.
}

Press of Gibson Bros, Washington, D. C. 


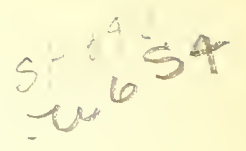

\section{LOUISIANA PURCHASE EXPOSITION.}

U. S. Commission of Fish and Fisheries.

George M. Bowers, U. S. Commissioner of Fish and Fisheries.

W. de C. Ravenel, Representative on U. S. Government Board.

STAFF,

George A. Schneider, Superintendent of Construction of Aquarium.

I. H. Dunlap, Assembling and Installing Exhibit of Fishery Products.

H. F. Moore, Assembling and Installing Scientific Inquiry Exhibit.

L. G. Harron, Superintendent of Aquarium.

W. E. Morgan, Special Agent.

J. J. Glennan, Mechanical Engineer in Charge.

W. P. Sauerhoff, Fish Culturist.

Miss E. W. Isamon, in Charge of Accounts.

COLLABORATORS.

A. H. Baldwin, Washington, D. C.

S. P. Bartlett, Illinois Fish Commission, Quincy, Ill.

H. von Bayer, U. S. Fish Commission, Washington, D. C.

C. L. Bristol, representing Colony of Bermuda.

J. E. Brown, U. S. Fish Commission, Washington, D. C.

Nat H. Cohen, Illinois Fish Commission, Urbana, Ill.

H. D. Dean, U. S. Fish Commission, Neosho, Mo.

B. W. Evermann, U. S. Fish Commission, Washington, D. C.

J. F. Ellis, U. S. Fish Commission, Washington, D. C.

James A. Henshall, U. S. Fish Commission, Bozeman, Mont.

R. S. Johnson, U. S. Fish Commission, Manchester, Ia.

G. H. Lambson, U. S. Fish Commission, Baird, Cal.

W. C. Little, Atlantic City, N. J.

E. F. Locke, U. S. Fish Commission, Woods Hole, Mass.

M. C. Marsh, U. S. Fish Commission, Washington, D. C.

A. D. Mead, Rhode Island Fish Commission, Providence, R. I.

R. M. Mullett, U. S. Fish Commission, Washington, D. C.

James Nevin, Wisconsin Fish Commission, Madison, Wis.

.H. M. Şmith, U. S. Fish Commission, Washington, D. C.

ษั

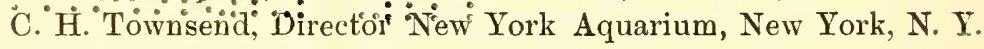

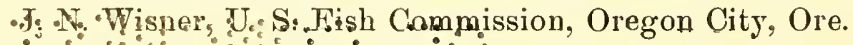

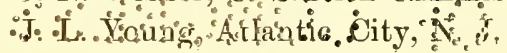

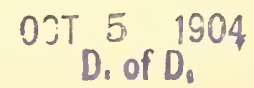




\section{The United States Commission of Fish and Fisheries, and its Exhibit at the Louisiana Purchase Exposition, St. Louis, Missouri, rgo4.}

ESTABLISHMENT AND GROWTH OF THE FISH COMMISSION.

In 1871 Congress passed a joint resolution authorizing the President to appoint a Commissioner of Fish and Fisheries, whose duties were thus defined: "To prosecute investigations on the subject (of the diminution of valuable fishes) with the view of ascertaining whether any and what diminution in the number of food-fishes of the coast and the lakes of the United States has taken place: and, if so, to what causes the same is due; and also whether any and what protection, prohibitory or precautionary measures should be adopted in the premises, and to report upon the same to Congress."

Subsequent legislation from time to time extended the duties of the Commissioner, and finally led to the formation of the Fish Commission. The propagation and distribution of food-fishes, which soon became the most important work of the Commission, was inaugurated under authority of an act of Congress in 1872. A study of the methods and statistics of the fisheries was specifically authorized in 1879 and has since been regularly carried on. The biological and economic inquiries provided for in the original act have been continued uninterruptedly and have greatly increased in scope and rnagnitude.

By act of Congress approved February 14, 1903, the Fish Commission was made a bureau of the new Department of Commerce and Labor, and on June 30, 1903, it terminated its independent existence.

\section{PRESENT FUNCTIONS AND ORGANIZATION.}

The work of the Commission, for convenience of administration, is conducted under three main heads:

(1) The multiplication of useful food animals and the stocking of waters therewith.

(2) The investigation of the interior, coastal, and off-shore waters of the United States, with reference to biological and physical problems, including a study of the life histories of food-fishes and other economic animals, as well as the life histories of the animals and plants upon which they feed or upon which their food is nourished.

(3) The investigation of the present and past methods of the fisheries in their relation to the catch and the preservation of the supply, and the 
collection of statistics of the commercial fisheries of the United States, including persons engaged; vessels, apparatus, and capital employed, and quantity and value of the products taken.

Since 1871 the Commission has published an annual report in which its various operations are referred to in detail, and, in addition, many important articles pertaining to fish-culture, fisheries, and biological investigations in the United States and foreign countries have appeared as appendices. In 1880 the publication of the Bulletin of the United States Fish Commission was begun, and volumes have since appeared yearly. This volume contains matter of the same general character as the appendix to the annual reports.

WHAT THE FISH COMMISSION IS DOING.

The Commission has acquired a world-wide reputation on account of the character, magnitude, and results of its operations, and has achieved marked success in many lines of economic and scientific work.

In 1903 the work of propagating food-fishes and stocking public waters therewith was more successful than in any previous year. The number of hatcheries operated was 46 , and the number of eggs and fish distributed exceeded one and a quarter billions. The species of fishes distributed numbered about 50, and included the leading food and game fishes of the lakes and river's as well as many important salt-water forms. The lobster, most valuable of our crustaceans, is hatched at two stations in Massachusetts, and a special lobster hatchery has recently been established on the coast of Maine.

Up to the present time the Commission's output of food-fishes has exceeded 13 billions, aud very important effects have followed the cultivation of fishes on such an immense scale. Depleted waters have been restocked, the supply of certain species has been maintained or increased in spite of very extensive fishing; and fishes have been introduced into new waters where they have proved of great economic value.

The recent biological investigations have covered a wide range and have been addressed to some of the most vital matters affecting the fishing industry and the artificial propagation of fishes. The oyster, the leading water product, has deservedly received much attention; and progress has been made in the important experiments having for their object the fattening of oysters by artificially increasing their natural food. The lobster, the blue crab, the diamond-back terrapin, the Atlantic and Pacific salmons, the commercial sponges of Florida, and numerous other fishery objects have been studied in their biologico-economic aspects. The aquatic resources of the Hawaiian Islands and the salmon industry of Alaska have recently been exhaustively considered.

Statistical canvasses of the entire fishing industry of the Middle Atlantic, South Atlantic, and Gulf States, were carried on in 1903, and a number of statistical inquiries were addressed to special States and Territories, as Alaska and Porto Rico. 


\section{THE LOUISIANA PURCHASE EXPOSITION.}

STATUS OF THE UNITED STATES FISH COMMISSION.

The act of Congress approved March 1, 1901, providing for the participation of the government departments and bureaus in the Louisiana Purchase Exposition, mentioned specifically the United States Commission of Fish and Fisheries. The Commissioner appointed Mr. W. de C. Ravenel, assistant in charge of fish-culture, as the representative of the Commission on the government board of management; and detailed other employees from time to time to assist in the preparation, installation, and care of the exhibit.

Owing to the peculiar nature of the exhibit, involving an extensive fresh and salt-water aquarium and also the use of water for other purposes, it was adjudged desirable by the government board to provide an independent building for the Fish Commission exhibit.

THE BUILDING AND THE AQUARIUM.

The government fisheries building, located 175 feet west of the main government building, is 136 feet square, with a central open court 74 feet square. The exterior of the structure is in classical Grecian style, while the interior resembles a Pompeian atrium. The facades are ornamented by Ionic columns, 36 feet high and 4 feet in diameter, engaged for threefourths of their height but free above and supporting an open loggia. Alternating with the columns are fountains playing into large basins resting on the backs of turtles, and over each fountain is a group of four generic names of American fishes, marine shore fishes being represented on the east and north walls, pelagic and deep-sea fishes on the south wall, and fresh-wvater fishes on the west wall.

In the open court is displayed the general exhibit of the Fish Commission, which occupies 5,476 square feet. In the center is a pool, 24 feet square, open to the sky and surrounded by 12 Doric columns, 3 feet 10 inches in diameter, which support the roof. In addition to the conventional ornaments appropriate to such a building, shells, dolphins, and fish-forms have been freely introduced.

The aquarium comprises 40 tanks, which line the walls of the building, and cover's 13,000 square feet. The tanks are of various sizes: two are 12 feet long, 6 feet high and 7 feet wide; four are 5 feet long, $3 \frac{1}{2}$ feet high and 5 feet wide; five are 3 feet long, 2 feet high and 2 feet wide, and twenty-nine are 7 feet long, $3 \frac{1}{2}$ feet high and 6 feet wide. The aquarium is separated from the case exhibit and the square central court, which it surrounds, by corridors 15 feet 9 inches wide; these are in semi-darkness, while the tanks are lighted only from the rear, so that the animals are plainly visible and the general effect is very pleasing. Opposite the tanks the walls of the corridors are covered with a continuous series of plateglass mirrors, which reflect the tanks and give the effect of increased size.

The aquarium is constructed in the romanesque style, in keeping with the remainder of the interior. Across the ceiling of the corridor's are beams supported on pilasters on either side of the tanks and forming 
deep panels. Over each tank is a large circular window for ventilating purposes, and lower down there is a square window in which is fitted a comprehensive label of translucent paper lighted from behind.

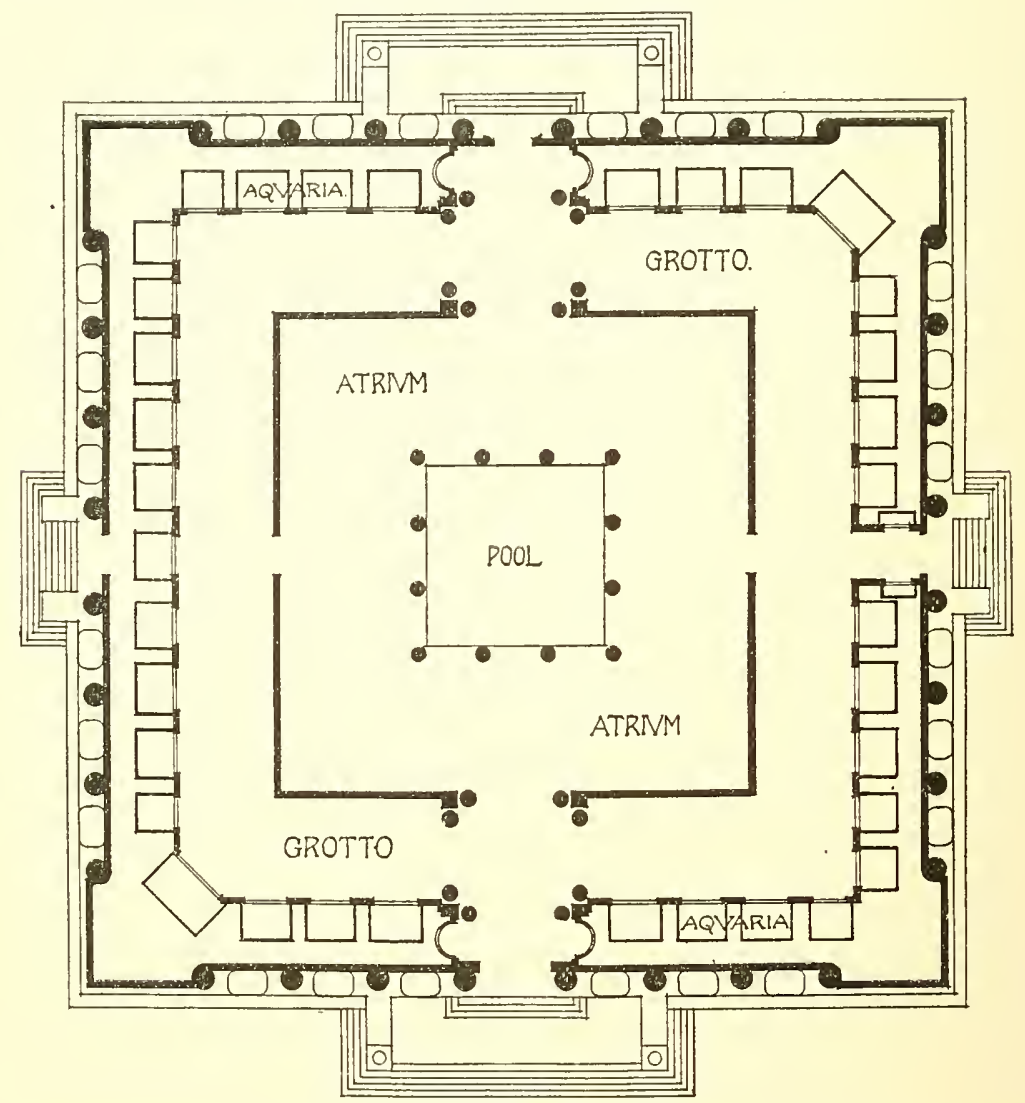

The machinery room, occupying 1,728 square feet, is under the main floor ; in it are the electric pumps, filters, motors, air-pump, refrigerating machine, etc. Under the portico at the north entrance reservoir tanks for salt water and fresh water, with a capacity of 40,000 and 32,000 gallons respectively, are located.

GENERAL OUTLINE OF THE EXHIBIT.

Fish-culture.

Under this head are arranged those articles which illustrate the work of the Commission in the artificial propagation of food-fishes and the stocking of fresh and salt water therewith. The exhibit includes fullsized samples or models of apparatus and appliances used in collecting eggs, in hatching fresh-water and marine fishes, and in distributing fishes; also photographs, drawings and charts showing the methods of the work and some of the practical results of fish-culture. 
Throughout the Exposition there will be demonstrations of practical fish-hatching on a scale of considerable magnitude, many millions of eggs being utilized. Troughs are provided for the hatching of the eggs of the quinnat and other salmons of the Pacific coast, grayling, brook trout, rainbow trout, black-spotted trout, steelhead trout and other species having heavy eggs; tables are equipped with automatic jars and other jars for hatching eggs of the shad, pike perch and white-tish; and automatic tidal boxes are installed for the incubation of the floating eggs of the cod and other marine species.

A working model of the Cail fish-way, as improved by Mr. Hector von Bayer, engineer and architect of the Commission, shows the construction of the best ladder for enabling fish to surmount obstacles in streams.

A series of very effective mutascope pictures illustrates some of the phases of practical work in fish-culture addressed to various kinds of fishes.

In collaboration with the Rhode Island fish commission there is exhibited an exquisite model of a floating nursery for lobsters.

A model of a special railway car, such as is used by the Commission in transporting live fishes in all parts of the country, is shown; and on a railway siding near the Fish Commission building, one of the cars, employed in bringing fishes for the aquarium, may be inspected from time to time during the Exposition.

\section{Scientific Inquiry.}

The Division of Scientific Inquiry of the Commission is charged with the investigation of the various natural phenomena which bear upon the fisheries. These inquiries embrace researches upon the geographical distribution of fishes and other species of aquatic animals, their migrations and relative abundance under varying conditions, their food, enemies, parasites and diseases, as well as the study of those facts of embryology, growth, and habits which are essential to the development of rational methods of fish culture.

All branches of marine and fresh-water biology, as well as-the physical and chemical qualities of the water, have more or less direct bearing upon the fisheries, and a. wide scope must therefore be given to the investigation. Besides having the co-operation of other branches of the public service, the small permanent scientific force of the Commission is supplemented, during the summer months especially, by the employment of trained investigators from various institutions of learning.

This exhibit is designed to illustrate, as far as practicable, the character of the equipment maintained for the prosecution of these varied and widely distributed investigations, the methods employed; and some of the results attained. It is not possible to follow out this design with any degree of completeness, as much of the work lends itself not at all to the purposes of exhibition. Owing to lack of space, it is not even possible to show all of the apparatus used, much of which would be of little interest save in actual service. It has been deemed advisable, therefore, to exclude from the exhibit all such instruments and apparatus as are common to other branches of research, and which, like microscopes, 
microtomes, chemical apparatus, etc., are familiar objects to a large part of the public. The space allotted to this branch has been utilized for the display of apparatus used in making littoral and deep-sea investigations, much of which has been invented or modified by persons in the employ of the Commission.

Besides a number of smaller vessels, the Commission has two sea-going steamers, the Albatross and the Fish Hawk, models.nof which are shown on the central aisles. The Fish Hawk has varied duties, for in addition to earrying on marine biological investigations, she is also used during certain portions of the year as a hatchery for shad and other valuable marine animals. The maintenance of the shad fishery of the Delaware is largely due to her efficiency. The Albatross is designed especially for the investigation of the off-shore fisheries, and has had more service in deep-sea investigations than any other vessel in the world. She is an able sea-boat, and her equipment is especially complete and her laboratory facilities ample and convenient.

Adjoining the model of the Fish Hawk is a Tanner sounding machine with its equipment of instruments for physical research. This type of machine is used on both the Albatross and the Fish Hawk for depths not exceeding 500 fathoms, and in addition the former is equipped with a steam-power sounding engine for use in the greater depths of the sea.

Most of the types of collecting apparatus used by the Commission are shown in the exhibit running diagonally across the section. The large net on the-floor is a beam trawl, the most efficient net used for obtaining specimens from the ocean floor. The round iron hoops are not part of the net, but merely supports to exhibit it in the position which it assumes when in use. A net of this general type has been used by the Albatross. in a depth of 4,200 fathoms ( $4 \frac{3}{4}$ miles). Suspended from the ceiling above the beam trawl are types of apparatus used for collecting specimens from the surface, bottom or intermediate depths. The tangle is used where the bottom is too rocky for trawls or dredges, and it catches specimens by entangling them in its hemp swabs. The Chester dredge and the Smith dredge are two variants of the same type, and are designed to rake out and catch burrowing worms, mollusca, crustacea, etc. The ordinary dredges are used from small boats or from ships where the use of the beam trawl is impracticable. When brought on deck the contents of these various appliances are emptied into a series of sieves, where they are washed to remove the mud and sand, sorted by the naturalists, and preserved in suitable reagents for future study.

The large surface tow-net, which is lined with silk bolting cloth, is used to collect the swarming pelagic life of the sea. Though often individually insignificant, minute, or microscopic, the aggregate of this surface life is enormous and important, and it supplies, directly or indirectly, food for most aquatic animals.

The intermediate tow-nets, two types of which are exhibited, are used when it is desired to determine definitely the depth from which specimens are obtained. They are sent down vertically, towed horizontally at 
the required depth, and then closed by a mechanism actuated by a messenger or weight slid down the tow rope. No specimens are taken, therefore, either during descent or ascent, aud the investigator is furnished with important information concerning the vertical distribution of the forms which he studies. The Commission has recently adopted for field use a chest containing these various appliances in miniature adapted for use from small boats and launches. A chest containing a beam trawl, dredge, tangles, tow-net, sieves, etc., is exhibited.

Seines, gill-nets, scoop-nets, scrape-nets, and other appliances used in shore collecting are variously shown in the section, and collecting tanks and chests for the preservation and transportation of specimens are also exhibited in juxtaposition with the other apparatus.

The sponge fishery, which is confined to the State of Florida, is one of the most important of the local fisheries of the United States, and has recently been the subject of scientific inquiry and experiment. The natural beds have been depleted and some of the results of the Commission's experiments in artificial sponge culture are shown.

The oyster is by far the most important single product of our fisheries, and three cases are devoted to an exhibit to illustrate the anatomy, growth, local and accidental variations, enemies and other facts in its life history. In a section of the adjoining wall case some of the methods of oyster culture are shown.

Most of the space in the wall cases is devoted to the display of an exhibit prepared by the Rhode Island Commission of Inland Fisheries to illustrate the results of researches into the life history of various shellfishes conducted by that commission in collaboration with the United States Fish Commission. These preparations show the growth of the soft clam, scallop, oyster, lobster and starfish, bringing out important facts in their life histories. Lobster development is also especially illustrated by the microscopic preparations on an adjoining table. The starfish is one of the most destructive enemies of the oyster, and the other species are all economically important as food. Certain important facts not before known were brought out by these investigations, upon which have been based practical methods of clam and lobster culture and other suggestions of economic value.

Fishes, and especially those in captivity in ponds and artificial bodies of water, are susceptible to various diseases which sometimes produce serious epidemics. These are constantly under investigation by the Commission, and a few of them, with the organisms by which they are caused, are shown in a special case.

The exposition at St. Louis, though world-wide in its scope, is especially in relation to the Mississippi Valley, and the charts on the walls above the cases in the scientific section illustrate the geographical distribution of the more important food-fishes of that region.

\section{Methods and Statistics of the Fisheries.}

The division of the Commission concerned with the methods and statistics of the United States fisheries conducts inquiries through a regular 
corps of agents for the purpose of showing the extent and condition of the fishing industry, the chief apparatus and methods employed, and the changes taking place in our fisheries from year to year. The most complete and accurate statistics are gathered and published from time to time for gratuitous distribution. Preliminary condensed one-sheet bulletins are issued, and later the detailed tables, with appropriate text, are printed in the regular reports of the Commission.

The commercial fisheries of the United States, as determined by the Commission, represent an investment of about $\$ 76,000,000$, give employment to over 215,000 people, and are worth $\$ 50,000,000$ or more to the fishermen annually. Fish and other water animals contribute largely to the food supply of the country. These are placed on the market in a large variety of conditions; although mostly sold fresh, many are salted, smoked, canned, etc., so that the usefulness is increased by the possibility of shipping them long distances and preserving them indefinitely. In this exhibit the principal food objects are shown in natural groups. Fishes are represented by stuffed and painted skins, and by colored and plain drawings, in addition to the living specimens in aquaria; oysters, clams and other mollusks occupy a number of cases, the collection embracing practically all those economically important for either food or bait; the exhibit of economic crustaceans is equally comprehensive, including nearly all the crabs, shrimps, lobsters and related forms which enter into the food supply or are employed as bait in the line fisheries; and terrapins, turtles and other edible reptiles are represented by a series of polished shells.

The leading food products of the fisheries are shown in a small but comprehensive display of canned, smoked, salted and pickled goods.

The secondary products of the fisheries, also of considerable and increasing value, are illustrated as completely as possible. The principal of these are fertilizers, glues, oils and isinglass. From the skins of cod, cusk and other fishes, a superior glue is manufactured which is taking the place of most other adhesives, and is susceptible of being prepared for many special purposes; being in liquid form it is more convenient for use. These skins were formerly thrown away as waste, but now, after having been cooked and the glue extracted, they are again used in the manufacture of an excellent fertilizer. Fertilizer is also produced from the waste in canning various other species and from the residuum of fish oil. The best and most extensively manufactured fish fertilizer is made from the menhaden, which is comparatively valueless as food and is found in great quantities along the Atlantic coast. Isinglass, used for clarifying beer and wine, for culinary purposes, and for its adhesive properties, is made from the air-bladders or sounds of various fishes. Of the domestic fishes, the sounds of the hake, weak-fish and cod are chiefly used, but numbers are imported-the Russian sounds obtained from the sturgeon being considered superior. A comprehensive series of oils, obtained from fishes, and valuable for medicinal or mechanical purposes, is shown. The best known and most extensively used are cod-liver, whale, 
sperm and menhaden oils, but many others are particularly adapted for special uses, for which they are superior to other animal and mineral oils, though the latter, on account of the relatively small cost, are superseding them. Porpoise-jaw and blackfish melon oil are especially valuable for clocks and watches and lubricating other delicate machinery.

The skins of water animals, including fishes, are largely utilized in the manufacture of leather goods of all kinds, and their use could probably be extended. Alligator leather is familiar to all, and the seal, walrus and sea-lion skins also furnish particularly fine leathers which are susceptible of being worked to a high degree of pliability, dyed in a great variety of colors, and, like alligator leather and the skins of some water snakes, are used for making bags, purses, cases, pocketbooks, belts, picture frames, etc. A number of these leather's, and others suitable for similar purposes, are shown, and include the skins as they appear when first tanned and the leathers dressed and dyed for different purposes. Porpoise leather is particularly valuable for shoes and shoe laces, being durable and waterproof, as is also leather made from the skin of the white whale or beluga, and the latter on account of its tensile strength is adapted for belting. Eel skins are used in great numbers in manufacturing whips. The skins of several species of rays and of the dog-fish, gar pike, whale, manatee and beaver are exhibited. The former are used by the Japanese for covering: sword hilts and for other ornamental purposes, and, as well as the others, to some extent in this country in manufacturing picture frames, fancy articles, and for other special purposes, though more coarse, brittle and harder to work than the leathers first mentioned.

Ivory, bone and shell are among the products of the fisheries used to a certain extent in the arts and industries, and there are shown examples of walrus and narwhal tusks, sperm-whale teeth, baleen or whalebone, and the well-known tortoise shell in the form of shells, rough and polished, of the hawksbill or tortoise-shell turtle.

The shells of mollusks are employed for various purposes. A comparatively new use to which those of our fresh-water mussels have been put is in the manufacture of pearl buttons. This business, while only established a few years ago, has attained large proportions in the Mississippi basin. A full series of the shells utilized in button-making is shown, together with buttons in various stages of manufacture. The mollusks yielding shells suitable for buttons also produce beautiful and valuable pearls and baroque pearls, examples of which are exhibited. The better grades of pearl buttons and ornaments are produced from marine shells, which afford a finer and more lustrous grade of mother-of-pearl. These are found principally in tropical waters, and brought to the United States for manufacture. The so-called pearl-oyster, which is the principal shell utilized, is found in the Gulf of California and in the Philippines, and the abalone is common on the California coast.

The fisheries supply valuable articles of wearing apparel in the form of furs, which are shown in their natural state and "plucked and dyed" ready for manufacture. Large numbers of fur-seal skins are still obtained 
annually from the seal fisheries controlled by the United States on the Pribilof Islands in Alaska. These are considered the best and are commercially known as Alaska seal. Nearly all seal skins are dressed and dyed in Europe and returned to this country in a finished state ready to be made into garments. The sea otter found in Alaska furnishes the most valuable fur, and is comparatively rare. It is mainly used as a trimming for coats and garments, and, as it has naturally a peculiar delicate silvery appearance, it is not dyed. Other fur-bearing aquatic animals taken in various parts of the United States are the fresh-water otter, beaver, and muskrat, an enormous number of the skins of the latter being taken annually. A coarse fur, from which are manufactured robes, cheap gloves, etc., is obtained from the common hair seal of the Atlantic coast.

Among other objects related to the fisheries are shown seaweeds mounted and prepared for market. These are utilized in this country to some extent in preparing food, for fertilizers, etc., and many varieties common along our coasts are extensively used in foreign countries, and are of commercial importance. From some species iodine is obtained.

In curing fish different kinds of salt are employed, the choice being governed by the strength and coarseness as applied to different fishes. In New England, Trapani salt, imported from Sicily, is used for cod, haddock, halibut, and other coarse fishes, and Liverpool salt, though less strong and clean, for mackerel, because of the smaller grains. On the Southeru rivers and coast, Turks Island salt is found desirable, while on the Great Lakes domestic salt is used. On the Pacific coast marine salt, made by evaporating sea water, is most economical and is of excellent quality. For the manufacture of caviar a fine salt, imported from Germany and known as Luneburg, is especially prepared.

The apparatus and methods of the commercial fisheries are fully illustrated by actual specimens, by models, by colored photographic enlargements and by mutascope scenes.

Models of the types of modern fishing vessels illustrate the vessel fisheries of the Atlantic and Pacific oceans and the Gulf of Mexico, particular attention being paid to the Grand Bank cod-fishing, the mackerel fishery, and the market fishery of Gloucester and Boston, Massachusetts. The various types of pound nets, seines, trawls, hand lines, etc., used in the commercial fisheries are illustrated by models and by full-sized specimens where space permits, together with dredges, tongs and other articles used for taking oysters, scallops, clams, turtles and sponges.

One of the most interesting exhibits is a collection of the various types of swivel guns, shoulder guns, rocket guns, harpoons, lances and other implements that have beeu used for the capture and handling of whales by the fishermen of this country.

Among the specially instructive exhibits illustrating fishing methods and apparatus are a large working model of a Columbia river salmon wheel, a model of the Florida sponge fishery, and models of some of the most important of the marine fisheries of the northeastern coast. 


\section{CATALOGUE OF THE EXHIBIT.}

SYNOPSIS,

I. The U. S. Fish Commission as a whole.

II. The Propagation and Distribution of Food-fishes.

III. Scientific Research.

IV. Apparatus, Methods, and Statistics of the Fisheries.

V. Objects and Products of the Fisheries.

VI. The Aquarium.

\section{THE UNITED STATES FISH COMMISSION AS A WHOLE.}

Portraits of the Commissioners:

Spencer F. Baird, 1871-1887.

G. Brown Goode, 1887-1888.

Marshall McDonald, 1888-1895.

John J. Brice, 1896-1898.

George M. Bowers, 1898 to present time.

\section{Publications of the Commission:}

Annual reports of the U. S. Commission of Fish and Fisheries, 1870 to 1902, 29 volumes, octavo.

Bulletins of the United States Fisl Commission, 1880 to 1902, 22 volumes, octavo and royal octavo.

The Fisheries and Fishery Industries of the United States, 7 volumes, quarto, $1884-7$.

\section{THE PROPAGATION AND DISTRIBUTION OF FOOD.FISHES.}

\section{Practical Fish-cultural Operations.}

Demonstrations of methods of hatching fish eggs and of holding the fry, throughout the Exposition:

(a) Eggs of shad, pike perch, white-fish, etc., hatching in jars.

(b) Eggs of salmon, trout, grayling, etc., hatching on trays.

(c) Fry of these fishes in aquaria and in troughs.

Mutascope demonstrations of fish-cultural methods and operations :

Taking and fertilizing eggs of cod, Kittery Point, Me.

Taking shad eggs, Potomac river.

Catching, sorting, and spawning pike perch, Lake Champlain, Vermont.

Model of Clackamas River, Oregon.

The Clackamas is one of the principal salmon streams in the basin of the Columbia, having important fisheries and also being the site of extensive fish-cultural work. The model represents the bed of the river, with rack, traps, and pens used for intercepting, catching, and retaining salmon from which eggs are to be taken for hatching purposes.

Improved Cail Fishway.

[Scale of model, 1 inch to the foot. Inclination, 1 to 4 .]

A series of comparatively still-water compartments arranged in steps and separated by cross bulkheads with suitable openings allowing the fish to ascend the fishway by either leaping the small waterfalls over the bulkheads or passing through the openings. This fishway can be constructed of either timber, masonry, or concrete, and on a straight line or angles and curves, as the conditions may require. It is applicable to the various forms of existing dams and natural falls, and owing to the abundance of light through the open spaces on top ean be readily inspected and the débris 
easily removed. Protection against drift ice and logs during freshets is provided, and there are no regulating gates or other devices requiring an attendant. The floor compartments are slightly inclined, and the bulkheads run obliquely in order that the current passing through can readily clear gravel, sand, mud, and other rubbish, which is an improvement over many other types of fishways. The original fishway was designed by Mr. Richard Cail and is used successfully in Scotland.

Improvements were made by $\mathrm{H}$. von Bayer, architect and eugineer of the U. S. Fish Commission, as follows: (1) Beginning at the top the openings in bulkheads are decreased successively so as to insure an overflow over each bulkhead down to the lowermost in case of any leakage in the fishway. (2) The bulkhends are placed obliquely across the fishway, so as to make each compartment self-cleaning.

\section{Results of Fish-culture.}

Chart illustrating the effects of artificial propagation on the shad fishery.

Apparatus for Transporting Eggs.

\section{Clark white-fish egg box:}

Wooden case, with hinged door, containing twenty trays. This case is used chiefly for the transportation of the eggs of the white-fish aud lake trout from field stations on the Great Lakes, and was designed by Mr. Frank N. Clark, of Northville, Nich. Eggs have frequently been held on these eases from fifteen to thirty days before they reached the hatchery, without suffering material loss.

Annin's egg-transportation box:

This apparatus consists of an outer case which coutains a smaller one, surrounded by sawdust to prevent loss of eggs from sudden change of temperature. The inner case is provided with trays, with canton-flannel bottoms, for holding the eggs. There is a small ice chamber between the outer and inner boxes, and the bottom of the outer box is provided with wooden strips to prevent its coming in contact with the surface on which it rests, which would prevent drainage.

Devised by James Annin, Jr., Caledonia, N. Y. Boxes of this patent have been used for sendùng eggs of trout to Europe.

\section{Atkins's transportation box:}

A wooden box containing three smaller boxes, in each of which 15,000 salmon eggs are placed upon layers of muslin. The space between the larger and smaller boxes is filled with moss to prevent an unhealthy change of temperature, and the layers of eggs are separated from each other by wet moss. Eggs packed in this way can be sent several thousand miles with very satisfactory results.

Devised by Charles G. Atkins, East Orland, Me.

\section{Seagle's egg-transportation box:}

This apparatus consists of a wooden box, with hinged cover, 21 inches long, 19 inches wide, and $18 \frac{1}{2}$ inches high, containing 6 canton-flannel trays, $11 \frac{1}{2}$ inches by $9 \frac{1}{2}$ inches, on which the eggs are placed, packed in moss. A wooden hopper above the trays holds crushed ice, and the space around the trays is tightly packed with sphagnum moss. Eggs of the Salmonidæe are successfully transported long distances by means of this apparatus.

Devised by George A. Seagle, Wytheville, Va.

\section{McDonald's egg-transportation crate:}

A crate containing eighteen shallow trays or wooden frames, with wire-cloth bottoms, incased in canvas and secured by frames connected by leather straps. Length, 16 inches; height, 15 inches; width, 14 inches. This crate is used for transporting the eggs of the shad for a distance of 50 to 100 miles. The bottoms of the trays are covered with wet cloths, upon which the eggs are spread. Each tray holds from 10,000 to 15,000 shad eggs. When filled they are incased in the cloth cover, securely strapped together, and shipped by boat or rail to the hatchery. This apparatus marks the beginning of the dry transportation of shad eggs, and has been successfully used in the work of the U. S. Fish Commission since invented.

Invented by Marshall MeDonald, 1881.

\section{Apparatus and Accessories for Transporting Fry.}

Model of U.S. Fish Commission Car No. 3 (scale of 1 inch to the foot):

'This car was built in Wilmington, Del., by the Harlan \& Hollingsworth Company in the month of November, 1897. Total length of frame, 60 feet; width of frame. 
9 feet 6 inches; total length of car from ends of platforms, 67 feet 10 inches ; height of car from top of rail to top of roof, 13 feet 10 inches. The frame of the car has a special bracing in order to allow the two large doors in the center of the car to extend from floor to roof. The trucks for the car were made by the Pullman Company, each of them having six 33.inch Allen paper wheels. The interior finish of the car is of light-color ash. In one end of the car is an office, and next to it an ice bux-capacity of about $1 \frac{1}{2}$ tons-and a water tank holding about 500 gallons. In the center o: the car are two compartments for carrying its load. The fish are carried in cans aud square tanks, according to the size of the fish. The size of these compartments is 30 feet long, 3 feet wide, and 25 inches deep. A hatching apparatus of a capacity of 45 McDonald jars is also used on this car. and is placed on the top of the two compartments for carrying tish after moving the lids. 'The jars are placed in lead-lined boxes, which are of the same size as the lids and about 6 inches high. The supply of water is taken from the pressure tank. It flows from the lead-lined boxes through a system of piping to the storage tauk underneath the car. The hatching can be done while the car is in motion. In the otber end of the car is a kitchen and boiler room. The boiler room contains a 5-horsepower boiler, with water pumps and air pump for circulating the water and air on the fish. Underneath the car, between the trucks, is a storage tank which will hold about 600 gallons. The water is pumped from this tank to a pressure tank near the office end of the car, after which it circulates through the square tanks or batching apparatus in the center of the car, passing from these to the tank under the car again, so the water is used continuously. In the center of the car are four berths, together with a number of lockers and closets. The office contains one berth and a folcling bed; also a writing desk and closet. The kitchen is fully equipped with range, water tanks, etc.

\section{Transportation can :}

A cylindrical can, made of iron, tinned, the top of which is contracted and provided with a cover to prevent splashing of water while in transit. Height, 24 inches; diameter, 14 inches; capacity, 12 gallons. This can is more extensively used than any other form of apparatus for the transportation of young shad, white-fish, pike perch, trout, and other fishes distributed by the U. S. Fish Commission.

\section{Galvanized-iron transportation tank :}

This tank (size, 24 by 24 by 24) is used on U. S. Fish Commission cars for transporting adult fishes and yearlings over 6 inches in length. It is so arranged as to receive a continuous supply of air, and can also be connected up with the watersupply tanks so that a continuous circulation of water is maintained.

\section{Tin pail for rock buss:}

A light tin pail, with a capacity of 2 to 4 quarts, used in shipping rock bass and bream by express.

\section{Bucksport transportation can :}

A cylindrical can, made of block tin, with top contracted, and provicled with a cover, 18 inches in height and $15 \frac{1}{2}$ inches in diameter at base. This can is used entirely at the Craig Brook (Maine) Station for transportation of salmon fry.

\section{Messenger bucket:}

This bucket forms a part of a messenger's equipment, and is used for carrying extra ice, changing water, etc.

Quart dipper :

A part of the messenger outfit, used for aeration of water, sorting fish, etc.

\section{Siphon cage:}

Made of copper and tin. It is covered with cheesecloth and attached to the siphon tube for drawing off water from aquarium or cans containing fry.

\section{Tin siphon funnel :}

A cylindrical funnel, with fine perforations at bottom, a part of the messenger's outfit. Used in drawing off water from tanks containing shad and white-fish fry.

\section{Siphon tube:}

A piece of five-eighths rubber tubing, 4 feet long, used in connection with a siphon strainer for removing stale water trom cans containing young fish.

\section{Pocket thermometer :}

This forms a part of a messenger's equipment, and is regularly used for ascertaining the temperature of water while transporting fish. 


\section{Hatcheries, Hatching Apparatus and AcCessories.}

Model of Leadville trout hatchery (scale of model, three-fourths inch to 1 foot):

The station is located in Lake County. Colo., 6 miles west of Leadville, on a government reservation of 1,935 acres. It was established by act of Congress approved March 2, 1899, for the purpose of propagating black-spotted and other native species of trout, as well as various fishes of the salmon family from the Eastern stations. The hatchery is built of red sandstone, is equipped with 72 troughs, each 14 feet long, 14 inches wide, and 8 inches deep. It has a total capacity of $6,000,000$ tront eggs. The water supply is obtained from Rock Creek and springs on the reservation. The temperature of the water throughout the year varies from $37^{\circ}$ to $46^{\circ}$, the mean being $43^{\circ}$.

\section{Model of hatching barge:}

'The barges were generally equipped with hatching cones and Ferguson plunging buckets, and were extensively used by the U. S. Fish Commission for many years in the waters of Noth Carolina, Virginia, and Maryland in batching the eggs of the shad. After the establishment of permanent shore stations the use of the barges was abandoned.

\section{Cod box :}

This apparatus consists of a series of double rectangular wooden boxes, usually arranged in nests of 8 or 9 . The eggs are placed in the inner box, the bottom of which is slightly oval instead of flat, and is covered with scrim cloth. The water is introduced from the water chamber through the bottom and through a hole several inches above the bottom, which gives the eggs a slightly rotary motion; it escapes through an intermittent siphon, which produces the tidal motion essential in hatching floating, eggs.

Originally designed by Marshall McDonald in 1880 and perfected in 1888.

\section{Model of plunging buckets:}

This model illustrates the methods employed in hatching shad during the early days of the Commission. It was invented by Maj. T. B. Ferguson in 1880 and was used in the Chesapeake Bay and on the Albemarle Sound. The plunging buckets were on the outside of a barge which was fitted up with the machinery necessary for operating the same. It has also beeu used with slight success in the hatching of floating eggs.

\section{McDonald's Y-shaped hatching box:}

A wooden box, with glass ends and sloping sides, for eggs. Length, 12 inches; width, 24 inches; depth, 15 inches. The sides of the box slope toward the bottom center until they come within an inch of each other. Below this opening is a space 3 or 4 inches deep, for the introduction of water. 'I'his opening is nearly closed by means of an adjustable square wooden bar, one of the angles of which enters the center of the opening. the sides of the bar thus being parallel with those of the box. $\mathrm{By}$ this means the current is divided, so that the water is deflected along either side of the box toward the surface, carrying the eggs with it and causing them to pass in toward the center and fall again to the bottom, where they are again caught by the current and carried through the same circuit. The outlet is protected by a triangular trough runuing across the top center from side to side. This is placed a little below the top of the box, so that the water shall flow over its side and ont through the openings. The current introduced is sufficiently strong to carry dead eggs into this trough, thus allowing them to escape, but not strong enongh to carry away the good eggs, which, being heavier than the dead ones, drop before reaching the trough. Great care must be taken to see that the flow of water is properly adjusted, otherwise many of the dead eggs may be retained or the good ones may be lost.

Invented by Marshall MeDouald in 1881.

\section{Williamson hatching trough with Stone salmon basket:}

A section of the hatching trough, showing three compartments complete, with three tiers of wire trays in each. In the trough a double partition separates each compartment, the first extending from the bottom of trough to within an inch of the top, while the second extends from the top to within an inch of the bottom, the two sections of the partitioning being 1 inch apart. The water passing over the first partition and under the second, into the compartment, forces its way up through the eggs on the baskets and over and under the next partitions. 
Trout trough with wire trays :

This is an ordinary trout trough, 8 feet long, $12 \frac{1}{8}$ inches wide in the clear, and 6 inches deep, titted with ordinary galvanized-iron wire trays, 7 meshes to the inch. Used at most of the hatcheries in the Commission for hatching brook, rainbow, and black-spotted trout eggs. The troughs in the hatcheries vary in length from 12 to 16 feet. Both the trays and troughs are painted with asphaltum varnish. Wire trays for the hatching of trout eggs were first used in 1867 by Mr. E. A. Brackett, of Winchester, Mass.

\section{Ferguson hatching-jar :}

A cylindrical jar of glass, with a contraction near the base, which serves as a support to the 7 wire-cloth egg-trays which it contains. It has two circular openings on opposite sides-one at the bottom for admitting the water, which passes upward through the eggs and out throngh the second opening, which is situated at the top. Height, 12 inches: diameter, 8 inches. For economy of water, the outflow opening of one jar is connected with the inflow pipe of the next by means of rubber tubing. By this means the water passes through an entire series of jars before it finally escapes. The jar is used chiefly for hatching eggs of the Salmonidæ. It holds about 4,000 salmon eggs or 6,000 trout eggs.

Invented by T. B. Ferguson, 1876 .

\section{Atkins's hatching-crate:}

A frame of metal and wood, with hinged cover, which incloses a nest of 9 eggtrays. Length, 12 inches; width, 12 inches; depth, 7 inches. This crate is used chiefly for hatching eggs of the Salmonidæ. The trays are provided with corner strips of wood, which separate them slightly from each uther to allow free circulation of water, though the spaces are not large enough to allow the escape of eggs. These crates can be placed either in the open stream or in ordinary troughs.

Designed by Charles G. Atkins, Bucksport, Me.; presented by Mr. Atkins,

\section{McDonald hatching-jar, old style:}

Similar to improved jar now in use: but. instead of a metal cap, cork was used for the stopple. Invented in 1881; superseded in 1883 by improved McDonald jar.

\section{Chase hatching-jar :}

A cylindrical jar of glass, with a metal rim notched at one side and provided with a wire screen for retaining the fish. The water is introduced through a glass tube at the bottom and passes upward through the eggs. Height, 16 inches; diameter, 6 inches. This jar is extensively used for hatching. eggs of the white-fish. When the embryos are leveloping the outflow gate remains open, and through it any dead eygs are carried upward by the current and escape, thus preventing the injurious effects which arise from fungus and dead eggs.

Invented by Oren M. Chase, Detroit, Micli.

\section{Clark hatching-jar:}

A cylindrical jar of glass, with a metal rim, having a spout at one side, from which the surplus water escapes. The bottom of the jar is provided with a metal cone corresponding with the funnel-shaped end of the supply tube, which is prevented from coming in contact with it by means of slight projections on its inner surface. Height, 18 inches; diameter, 6 inches. This jar is coming into favor for batching eggs of the white-fish, and is used extensively at the Northville hatchery.

Designed by Frank N. Clark, Northville, Mich.

\section{Mc Donald white-fish jar :}

'This is the same as the jar used for hatching shad, known as the McDonald universal hatching-jar, with the exception that the closed top is remored and an open top with a tin funnel $3 \frac{1}{2}$ inches long substituted in its place, through which the water escapes. The tube supplying the water is suspended from above to within one-eighth of an inch of the bottom of the jar, and is made of either glass, tin, or iron.

\section{McDonald's universal hatching-jar :}

A glass jar with metal cap, containing two circular openings. Through one of these, which is situated in the center, a glass tube for the introduction of water passes to within a short distance of the bottom of the jar. The other, situated near one 
side, contains a shorter glass tube, which serves as an outflow pipe. Height. 15 inches; diameter, 6, inches; capacity, 5 quarts. The McDonald jar is successfully employed in the hatching of various species of heavy eggs. The water in entering is thrown against the bottom with considerable force, and is deflected upward around the sides of the jar. The eggs, which tend to settle to the bottom, are carried upward along the sides, thence inward toward the center, from which point they again sink to the bottom. The current is regulated to give the desired motion to the eggs. With heavy eggs like those of the salmon there is no motion, but the water coming from beueath tends to buoy the eggs upward, thus preventing any injurious pressure on the lower ones by the mass above. The outflow pipe is movable, and can be lowered to a point where the dead eggs, which are lighter than the good ones, come in contact with it and are carried off. By this means the eggs are kept comparatively free from the injurions effects of fungus growth or decaying eggs. The jar can be filled two-thirds full of eggs with very satisfactory results, 75,000 shad eggs being considered a fair quantity.

Patented by Marshall McDonald, Washington, D. C., in 1882.

\section{Aquaria :}

Receptable, rectangular in shape, made of glass, slate, and iron; 48 inches long, 18 inches wide, 18 inches deep; into which the fry pass from the jars as soon as they are hatched. The aquaria is placed in the center of the hatching-table and receives the fry from abont 14 or 15 jars; as soon as they become crowded ihey are transferred to the fry troughs usually arranged around the hatehery.

Hand dip-net (aluminum):

A small net used at Central Station, Washington, D. C., for transferring single specimens from aquaria. Frame of brass wire. No. 11, American gauge, $3 \frac{1}{2}$ inches in diameter; handle of wood, 18 inches long; mesh of net, one-fourth and one-eighth inch by 6 inches deep.

\section{Trough net:}

Square frame of aluminum covered with fine-meshed netting and provided with handle for removing young salmon and other small fishes from hatching-troughs.

\section{White-fish dip-net :}

1 This net is used at Alpena Station in transferring the white-fish fry from receiving tanks to the transportation cans.

Jar scaff net:

Used for removing foreign matter from full jars of semi-buoyant eggs. Brass-wire frame and handle; bowl square or circular, $2 \frac{1}{2}$ inches to 3 inches in diameter; handle 19 inches long; netting of gilling twine, one-fourth inch mesh.

\section{Scaff net :}

Small square nets, with short handles of metal, for taking dirt from trout troughs.

\section{Siphon cage:}

Made of copper and tin. It is covered with cheese-cloth and attached to the siphon tube for drawing off water from aquarium or cans containing fry.

\section{Siphon cup:}

A tin cup placed under the end of a siphon to keep it from breaking when the water gets too low in the aquarium.

\section{Egg funnel :}

A shallow funnel especially designed for introducing fish eggs into the different kinds of hatchiug-jars. Netting made of gilling twine, one-fourth inch mesh is advantageously used over mouth of funnel to keep scales, etc., from going into the jar.

Tally board: Used for keeping count of trout fry and yearlings at Leadville, Colo.

\section{Liver strainer:}

An ordinary tin pan, with perforated bottom. The liver is passed through this strainer before feeding to the young fry, to insure its being thoroughly cut up. 


\section{Perforated ladle:}

An ordinary iron cooking ladle, with perforated bowl, used in handling trout eggs during the period of incubation in the hatching troughs.

Perforated dipper : Used in handling trout eggs during incubation.

Seagle hatching-trough: Model with sliding screen instead of fixed screen in head of trough. Advantage claimed in cleaning trough with young fish in it.

\section{Egg nippers :}

Made of wood, tin, and brass, of various styles, for removing dead and unimpregnated trout and salmon eggs.

\section{Page's egg scale:}

A small wooden square laid off in grades and numbers. The scale is designed to determine the number of eggs of any species in a McDonald hatching-jar. The grades correspond to one-half pint contents of the jar, and the number of eggs per half pint has been determined by counting 1 quart of eggs of each species.

\section{Measure for counting white-fish eggs:}

Devised by Mr. J. J. Stranahan, of Put-in Bay, Ohio, for counting rapidly a quart of white-fish eggs-applicible to any other species.

Feathers: Used in cleaning and manipulating trout and salmon eggs.

\section{Outfit and Apparatus for Collecting Fish Eggs.}

\section{The spawn-taker:}

This lay figure represents a man in the act of taking the eggs from a ripe salmon. The fish casts in front of him show the condition of the ovaries and spermaries of ripe male and female salmon.

\section{Spazon-taker's bucket:}

Part of a spawn-taker's outfit, and is principally used in the collection of shad eggs. After the eggs have been fertilized and all of the pans refilled they are emptied into the bucket, where they are held until they reach the hatchery, the water being changed from time to time.

\section{Sparoning pans:}

May be of either tin, wood, or marbleized iron, and form a part of a spawn-taker's outfit in collectiug eggs of white-fish, trout, shad, etc.

\section{Collins's egg pan :}

An oblong pan with a tumble-in top, provided with an iron bail and cover, the latter preventing loss of eggs from slopping out, and the former facilitating the handling of apparatus in the boat. Pan is $18 \frac{1}{2}$ inches long, $10 \frac{1}{4}$ inches wide, $8 \frac{1}{2}$ inches high, without cover; tinued and shellacked inside to prevent the iron corroding from contact with sea water. Designed by Capt. J. W. Collins.

\section{Salmon spawoning box or jacket :}

A wooden box 42 inches long and tapering from $8 \frac{1}{2}$ inches to $3 \frac{1}{2}$ inches in height, and from 5 inches to $1 \frac{1}{2}$ inches in width. This box is used on the Columbia and Rogue rivers in stripping ripe salmon. The fish is placed on its back in the box, its head being secured with wooden slide and tail by a strap attached near the small end of the box, and is readily stripped by one man, whereas two or perhaps three men would be required without the box.

Invented by R. D. Hume, of Golden Beach, Oreg, in 1879.

\section{Photographs Illustrating Fish-cultural Operations.}

203 large photographs showing fish-eultural operations at stations and on vessels of the Fish Commission. 


\section{SCIENTIFIC RESEARCH.}

Vessels and Applianges for Deep-sea, Pelagic, Shore, and Fresh-water INVESTIGATIONS.

\section{Model of the Albatross:}

The steamer Albatross was built expressly for marine exploration, and intended es. pecially for investigating the off shore fisheries and fishing-grounds of the United States. It is an iron twin-screw steamer, and was built in 1882 by the Pusey \& Jones Company, of Wilmington, Del. General dimensions: Length, over all, 234 feet; at 12-foot water line, 200 feet; breadth of beam, 27 feet 6 inches; displacement, on 12-foot draft, 1,000 tons; registered tonnage, net, 400 tons.

The Albatross has recently carried on important investigations of the marine resources of the Hawaiian Islands and Alaska.

\section{Model of the Fish Hawk:}

The steamer Fish Hawk is a twin-screw propeller of 205.71 tons measurement; is rigged as a fore-and-aft schooner, with pole topmasts, and constructed for the combined purpose of fish-hatching and exploration. She was designed by Charles W. Copeland, and built in 1880 by Pusey \& Jones, of Wilnaington, Del. The work of fish-hatching necessitates her entering, at times, the shallow waters of rivers, bays, and sounds along the coast, and she was, therefore, given a light draft, which unsuits her for long trips at sea. The hull below the main deck is of iron, built on Lloyd's rules for vessels of her class, and sheathed with yellow pine $2 \frac{1}{2}$ to 3 inches thick. Above the main deck the structure is of wood. The hurricane deck extends from stem to stern and from side to side, on which are located the pilot house, captain's quarters, and laboratory. General dimensions: Length over all, 156 feet 6 inches; breadth of beam, 27 feet; mean draft, 6 feet $5 \frac{1}{2}$ inches.

\section{Tanner sounding machine and instruments for deep-sea physical research:}

The Tanner sounding machine is used in depths not exceeding 500 fathoms $(3,000$ feet). For greater depths the Sigsbee machine, which reels in sounding wire by steam power, is used. On both machines steel piano wire is used in place of the hemp sounding lines formerly employed, its advantages being strength, lightness, and small bulk. With it heavier sinkers can be employed to give an up-and-down trend, and its smaller surface per linear foot renders it less liable than the hemp lines to be diverted from the vertical by currents. A 65-pound shot on the sounding cylinder is automatically detached when the bottom is reached, in order to lessen the teusion when reeling in. The sounding cylinder brings up a specimen from the bottom, the water cup takes a sample of water within a few feet of the hottom, and the deep-sea thermometer automatically records the bottom temperature.

With the Sigsbee machine the Albatross recently found a depth of 4,813 fathoms (about $5 \frac{1}{2}$ miles), one of the deepest oceanic depressions in the world, about 100 miles southeast of Guam. The highest mountain in North America would be covered by nearly 2 miles of water if placed in this depression.

\section{Beam travol:}

A beam trawl is displayed, fully rigged and arranged in the position which it assumes when in use. This is the most efficient piece of apparatus employed in collecting specimens from the bottom of the sea, in either shallow or deep water. The one exhibited is the smallest used on the vessels of the U. S. Fish Commission, measuring 6 feet across the mouth; the largest form in general use is 11 feet across the mouth, and the other dimensions are correspondingly larger. The frame is composed of two iron runners connected at the top by a transverse beam of iron piping, to which the upper part of it is secured. The net consists of an onter bag about 18 feet long, having the lower side of its mouth heavily loaded with lead sinkers to insure its dragging closely on the bottom. Immediately back of the mouth it is provided with an internal, funuel-shaped apron, to prevent the escape of animals which have once entered, and for 6 feet at the bottom there is also an iuner pocket of small-meshed netting to hold the smaller specimens. A thick-walled spherical glass float is attached to the upper side of the net near the mouth, so as to hold it open when immersed. The lower end or tail of the net is closed by a secure lashing, which is removed after each haul for the discharge of the specimens into table sieves on the deck of the vessel, where they are washed, sorted, and preserved for futute study. The trawl is dragged by a steel rope which will bear a strain of 7 tons, rigged to a heavy bottom 
attached to the foremast. The trawl is lowered and hauled in by steam power. With a net in general design similar to the one exhibited the Albatross has obtained specimens in water over $4 \frac{3}{4}$ miles deep.

\section{Tangle bars :}

Used to collect specimeus where the bottom is so foul or rocky that the beam trawl, or any other form of net, would be torn or otherwise seriously injured. It is by no means as efficient as the trawl, but on rocky or coral bottom it is practically the only appliance which can be used, and it frequently catches numerous specimeus of starfishes, sea urchius, corals, crabs, shrimp, fishes, and other animals which become entangled in the mops. The bow at the angle of the bars is made of tempered steel, so that the legs will close up on one another like a pair of dividers if the frame becomes fouled in the rocks. The tangles are dragged over the bottom by the wire used for trawling.

\section{Chester rake dredge :}

For use from large vessels in collecting burrowing species of fish, mollusks, worms, etc., on hard mud or saud bottom.

\section{Smith rake dredge:}

For use from a small boat in collecting burrowing species of clams, worms, etc., on hard mud or sand bottom.

\section{Large boat-dredge :}

Used for collecting specimens from the bottom.

\section{Small boat-dredge:}

Used for collecting specimens from the bottom.

\section{Surface toro-net ( $3 \frac{1}{3}$ feet) :}

Used for collecting surface-swimming and floating plants and animals. The outer bag of netting serves as a support to the lining of cheesecloth used to retain the more minute orgauisms. The funnel prevents the escape of active species of shrimps and fishes. After a towing is made the tail lashing is removed and the specimens washed into a basin of water, from which they are picked out and transferred to preservatives. The net is usually towed at a speed of about 2 knots per hour.

\section{Tanner intermediate toro-net for taking specimens at known depths :}

This net is lowered vertically to the required depth and towed for a definite time. A weight or messenger is then sent down the wire, which reverses the tumbler, casts off the bridles, and allows the weights on the legs of the frame to exert a strong pull on the drawstring and securely close the bottom half of the net.

\section{Townsend intermediate tow-net :}

Used like the Tanner net. The ring is hinged and the two halves are closed on one another by a device actuated by a messenger slid down the rope.

\section{Surface tow-net (silk gauze) :}

Used for catching small and microscopic organisms at the surface.

\section{Baird seine :}

This is a type of seine especially devised and used for collecting fishes and, incidentally, other water animals. It is rigged with floats and leads like ordinary seines, but has as its distinctive features a very fine mesh and a large bag in the center where the catch gravitates and can be most conveniently overhauled. 'Two persons are required to operate it, and it may be set from a rowboat or by wading. The standard lengths of collecting seines used by the Commission are 15, 25, 45, 75, and 120 feet.

\section{Gill nets :}

Gill nets of various sizes and types, similar to those employed in the commercial fisheries, are used in collecting and determining the nature of the fish life in waters in which other kinds of apparatus cannot be so conveniently or effectively employed. 
Dip nets, scrape nets, etc.:

Various forms of hand nets, intended to be used from boats, wharves, or shores, are required in collecting small fishes and invertebrates that are swimming in the water, resting on the bottom, or attached to piling, rocks, etc.

\section{Collecting tank and chest:}

For use in the field and in shipping collections the Commission bas adopted a stout chest with handles and padlocks. The chest accommodates one 16-gallon tank, two 8-gallon tanks, or four 4-gallon tanks, made of sheet copper with tightly fitting screw tops.

\section{Portable collecting outfit:}

For use from small sailboats and launches. It consists of a chest containing : one 3-foot beam trawl, one 3-foot tangle frame and swabs, one small dredge, one 2-foot folding tow-net, one gauze tow-net, two seives with arms and brackets adjustable to the sides of any small craft, dredge ropes, etc. It can be carried as baggage.

\section{Speoral Orster Investigations.}

\section{Eastern oyster, anatomy, growoth, and enemies :}

Large model illustrating the anatomy of the oyster.

Shells corroded by boring sponge, showing on the inside face the new shell deposited by the oyster to cover up the perforations.

Shells overgrown with calcareous tubes of worm Serpula, which sometimes grow so densely as to kill or injure clusters of oysters by preventing their opening their shells.

Common starish (Asterias forbesii). A very destructive enemy of the oyster in Long Island Sound.

Common starfish (Asterias forbesii). Position commonly assumed when feeding. It turns the stomach inside out and projects it through its month and around its food. When satisfied the stomach is returned to its proper place.

Common starfish. Taken in the act of feeding on oysters. The starfish wrenches open the oyster by a long, steady pull, and then inserts its stomach between the valves as explained above aud absorbs the contents.

Oyster drill. Very destructive to oysters on certain parts of the Atlantic coast. By means of a rasplike tongue it drills a hole in the shell, through which it feeds on the soft parts of the oyster. It has unfortunately been introdnced with eastern oysters in San Francisco Bay.

Shells bored by drills.

Conch or "winkle" and egg cases (Fulgur carica). Oyster enemy. Not very destructive.

Conch or "winkle" and egg cases (Sycotypus canaliculatus). Oyster enemy. Not very destructive.

Cluster showing how the oysters are crowded by barnacles and mussels.

Overgrowth of barmacles on oyster.

Oyster three or four weeks old on planted oyster shells, Jong Island Sound.

Oyster two months old on planted stone, Long Island Sound.

Oyster one year old, hard bottom, Connecticut.

Oyster two years old, hard bottom, Connecticut.

Oyster three years old, hard bottom, Connecticut.

Oyster four years old, hard bottom, Connecticut.

Oyster five years old, hard bottom, Connecticut.

Oyster six years old, hard bottom, Connecticut.

Oyster less than six weoks old, on planted oyster shells, Louisiana.

Oyster less than one year old, South Carolina.

Oyster one year old, soft bottom, Connecticut.

Oyster two years old, soft bottom, Connecticut.

Oyster three years old, soft bottom, Connecticut.

Oyster four years old, soft bottom, Connecticut.

Oyster five years old, soft bottom, Connecticut.

Oyster six years old, soft bottom, Connecticut.

Oysters about seven months old, Narragansett Bay, R. I.

Oysters nearly two years old, Kickemuit river, R. I.

Oysters nearly three years old, Kickemuit river, R. I.

Oysters four years old, Kickemuit ıiver, R. I.

Oyster about fifteen years old, Kickemuit river, R. I., taken on beds of C. E. Bourne \& Sons. 
Oysters, set of 1901, Point Judith Pond, R. I., those on right having set in the eelgrass; $a$, still attached to a spear of grass.

Oysters, set of 1901, Point Judith Pond, R. I., taken up in October, 1902.

Oysters, set of 1901, Point Judith Pond, R. I., taken up October 20, 1903.

Oysters from Narrow river, Narragansett Bay, two years old, showing remarkable growth.

Eastern oysters attached to various objects:

Cluster of large oysters attached to old shell.

Young, on rubber shoe.

Growing on inside of bottle.

On piece of petrified wood.

Attached to rubber boot.

Young, attached to piece of old wood.

Growing on earthen ink bottle.

Growing on child's leather shoe.

Cluster attached to brick.

Growing from bowl of clay pipe.

Growing on palmetto pile.

Growing on twig of tree. In Florida some of the oysters, and in Porto Rico practically all of them are found attached to the mangroves near the surface of the water.

Young, growth or set on sheet of rubber, showing the density with which they some-

times attach themselves. The silvery shells are "jingles" (Anomia glabra).

Growing on bark planted as cultch to furnish place of attachment.

\section{Pacific oysters:}

Growing on shells of eastern oyster. The native oyster sometimes kills the introduced species by this overgrowth.

Growing around edge of cockle shell.

Dense growth of young on shells of eastern oysters.

From San Francisco Bay.

From Shoalwater Bay, Washington. These are regarded as the best native oysters on the Pacific coast.

From Port Townsend, Washington.

\section{Oyster culture :}

Jingle eulteh, planted to eatch young oysters.

Jingle cultch, with young oysters attached.

Broken stone cultch, planted to catch young oysters.

Stone cultch with young oysters attached.

Mussel shells, used as cultch to catch young oysters.

Mussel shells, with young oysters attached.

Pacific oyster, Fuget Sound, Wash., attached to old discarded netting from fish pounds, which is placed on the beds to catch the spat. This form of spat collector was first used by the Huntoon Oyster Company, and has many advantages. It is cheap, efficient, and the seed oyster's are easily handled for replanting.

Shiugles planted to eatch young oysters, Pacific coast.

Bark planted to catch young oysters, Pacific coast.

Volunteer growth from imported stock of eastern oyster, Fairhaven, Wash.

European oyster, Espevig, Norway, about four to six months old, attached to fascine or bundle of brush which is placed in the breeding ponds to catch the spat or young oyster.

European oyster, Espevig, Norway, about two years old, attached to fascine or bundle of brush which is placed in breeding ponds to catch the spat or young oyster.

European oyster, Espevig, Norway, about four to six months old, from cultivated beds.

European oyster, Espevig, Norway, about two years old, from cultivated beds.

European oyster, Espevig, Norway, about three years old, from eultivated beds.

\section{Special Investigations of the Soft-shell Clam (Mya arenaria).}

The investigations represented by this collection were made in Narragansett Bay, Rbode Island, by the Rhode Island Commission of Inland Fisheries in collaboration with the United States Fish Commission.

'The first six series of specimens illustrate the rate of growth of elams under several different conditions; the last series illustrates the difference in the rate of growth of clams of different sizes under the same conditions. 
The clams spawn from May to July, and attain sexual maturity in one yeal. They reach a length of three inches under especially favorable conditions in about one year and three months, but usually require two years.

The microscopic swimming larvæ, or spat, may be artificially collected, or may be found occasionally on the shore in great quantities. The raising of clams by trausplanting is practicable.

Soft clams, Kickemuit river, R. I., recently set and found clinging to seaweed; last of June, 1898.

Soft clams, shore of Cornelius Island, Wickford, 12. I., July 7, 1899; age of largest about 6.weeks.

Soft clams, shore of Cornelius Island, Wickford, R. I., August 29, 1899 ; age about 3 months.

Soft clams, shore of Cornelius Island, Wickford, R. I.; taken September 30, 1899; age about 4 months.

Soft clams, shore of Cornelius Island, Wickford, R. I., December 4, 1899 ; age about 6 months.

Soft clams, transplanted from shore of Cornelius Island, Wickford, R. I., to sandbox at house-boat, July 7, 1899 ; taken August 29, 1899; age about 3 months (same age as $I$.3, but larger).

Soft clams, transplanted from shore of Cornelius Island, Wickford, R. I., to sandbox at house-boat July 7, 1899; taken September 19, 1899; age, $3 \frac{1}{2}$ months (younger but larger than I.4).

Soft clams, difference between two specimens represents 2 months' growth; the larger was transplanted to a land-tile, set near low-water mark on July 22, when it was the size of the smaller specimen; taken up September 18.

Soft clams, transplanted to land-tile at low-water mark on July 18, 1899, when about $\frac{1}{2}$ inch long; taken up September 10, 1900; age, about 1 jear, 3 months.

Soft clams, shore of Kickemuit river, R. I.; taken December 4, 1899; age, about 6 months (same age, but larger than I .5).

Soft clams, caught in artificial spat-collectors when they were swimming larvæ, Wickford, R. I.; taken from collector August 14, 1900 (1,300 specimens caught in 1 square foot).

Soft clams, larger specimen transplanted from spat-collector to sand-box at houseboat August 14, 1900; taken up September 20 ( 5 weeks afterwards); the two smaller specimens left in covered spat-collector until September 20; difference in growth due to environment.

Soft clams, transplanted from spat-collector as in previous case; thence transplanted to boxes on shore in October, 1900; taken up Jannary 20, 1902; age, about 1 year, 8 months.

Soft clams, transplanted from spat-collector as in previous cases; thence transplanted to boxes on shore in Oetober, 1900; taken up January 17, 1903; age, about 2 years, 7 months.

Soft clams, transplanted from spat-collector as in previous cases; thence transplanted to boxes on shore in October, 1900; taken up October 22, 1903; age, about 3 years, 5 months; rather below the average size at this age.

Soft clams, from phenomenally thick set at Green's Island, Narragausett Bay, R. I.; taken August 17, 1901; 8,700 clams were taken in one shovelful of sand.

Soft clams, transplanted August 17, 1901, from Green's Island and Rumstick Point; taken up January 25,1902 ; age about 7 months.

Soft clans, upper specimen transplanted from Green's Islaud to Mill Cove, Wickford; lower specimen left at Green's Island; taken up January 20, 1903; age about $1 \frac{1}{2}$ years; represents average size.

Soft clains, upper specimen left at Green's Island; lower specimen transplanted from Green's Island to Mill Cove, Wickford, August 15, 1901 ; taken up December 11,1903 ; age about $2 \frac{1}{2}$ years; average size.

Soft clams, upper specimen transplanted from Green's Island to Mill Cove, Wickford, August 24, 1901; lower specimen transplanted from Green's Island to Kickemuit river, August 24, 1901 ; taken up about December 1, 1903 ; age about $2 \frac{1}{2}$ years.

Soft clams, notch filed in edge of shell February 20, 1903; clams then transplanted;

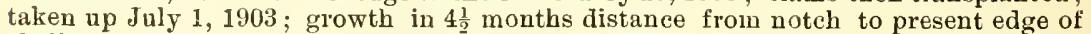
shell; age of upper specimen about 1 year, 1 month; age of lower specimen about 2 years, 1 month.

Soft clams, notch filed in edge of shell February 20, 1903 ; clams then transplanted; taken up August 10, 1903 ; growth in $5 \frac{1}{2}$ months $=$ distance from notch to present edge of shell.

Soft elams, notch filed in edge of shell February 20,1903; clams then transplanted, taken up October 20, 1903; growth in 8 months $=$ distance from notch to present edge of shell; age of upper specimen about 1 year, 5 months; age of lower specimen about 2 years, 5 months. 
Soft clams, notch filed in edge of shell February 20, 190:3; clams then transplanted; taken up Octaber 20,1903; growth in 8 months = distance from notch to present edge of shell (hardly any growth); age unknown, many years.

\section{Special Investigation of the Scallop (Pecten irradians).}

The investigation of the life history of the scallop was mare by the Rhode Island Commission of Inland Fisheries in collaboration with the United States Fish Commission. The mounted specimens illustrate the rate of growth of the scallops in Narragansett Bay, Rbode Island, during the first two years and four months.

The scallops die in great numbers in February and March of the second year, and rarely live two years. They spawn in June when one year old. The growth is rapid from June to December of the first and second years, but very slow from January to June. Immediately after spawning the period of rapid growth begins, causing a distinct growth line to appear on the shell, parallel to the margin. The presence of this line, therefore, indicates that the scallop is more than one year old. The comparatively few specimeus more than two years old have a second grow th line.

\section{Eighteen lots of scallops, illustrating rate of growoth :}

From Wickford, Greenwich, and other points in Rhode Island.

\section{Studies of the Starfish.}

The common starfish (Asterias forbesii) is very destructive to oysters, and a knowledge of its growth has an important economic bearing. All the specimens shown were reared at the bouse-boat of the Rhode Island Fish Commission, and their ages are accurately known.

Free-swimming young of starfish and the same "setting" on spears of eel-grass.

Starfish four days old (after setting); at this early age they begin to eat shellish.

Startish two and one-half weeks after setting.

Starfish three and one-half weeks after setting.

Starfish five weeks after setting.

Two starfish of the same age, ten weeks after setting; larger specimen well fed, smaller specimen (in riug) kept with little food.

Starfish seventeen weeks after setting.

\section{Experiments in Sponge Culture.}

At the present time sponges are obtained from the natural beds only, but the Commission is experimenting with a method of artificial sponge culture which gives great promise. Specimens of artificially giown sponges of several ages are exhibited.

\section{Specimen of bottom from the sponge grounds:}

This rock was detached during sponging operations near Anclote Key, Florida, and exhibits in approximately their natural appearance the marine growths attached. Besides other organisms, thirteen species of sponges were attached when the specimen was taken. Bottom of this general character is distributed in patches throughout the sponge grounds.

\section{Sheepswool, yellow, grass, and glove sponges :}

Showing condition and appearance when first taken from the water. 'The meshes are filled with a fleshy mass and the surface is corered by a dark skin perforated for the entrance and exit of water currents.

\section{Sponge cultivation :}

Sponge cuttings, attached to wire for purposes of artificial sponge culture.

Sponge cuttings, showing the extent to which the cut surfaces have healed after a month's growth.

Artificially grown sponges, about six months old, from cuttings.

Artiticially grown sponges, one year old, from cuttings.

Artificially grown sponges, two years old, from cnttings.

Artificially grown sponges, two and one-half years old, from cuttings. 


\section{ExPERIMENTS IN LOBSTER REARING.}

Model of the house-boat laboratory and apparatus used in raising newly-hatched lobster fry to the fourth, or lobsterling, stage (Scale, $\frac{1}{2}$ inch to the foot):

Young lobsters swim or float in the ocean for about two weeks after hatching. The skin is shed three times during this period, and after each moult the lobster appears in a different form. Immediately after the third monlt the precarious swimming habit is given up and the life at the bottom, with the characteristic habits of crawling, burrowing and hiding, begins. The many attempts to protect the young lobsters through this critical period have been thwarted by the peculiar difficulties of confining and feeding the fry, for in confinement they usually die from the effect of cannibalism, starvation, suffocation, or parasites.

The principal object of this apparatus is to keep the fry and their food suspended in the water by ereating, with the paddles, a constant upward swirling current. The machinery is run by a gasoline engine situated in one of the houses. From 16 to 50 per cent of the newly-hatched fry have been carried through to the fourth stage by means of this apparatus.

The house-boat is the marine station of the Rhode Island Commission of Inland Fisheries and is situated in Narragansett Bay at Wickford, Rhode Island. The experiments in raising lobsters were conducted by that commission in collaboration with the United States Fish Commission.

\section{Artificially reared lobsters :}

Lobsters in the first stage, one day old.

Lobsters in the second stage, having moulted once; about four days old ; reared artificially at Wickford, R. I.

Lobsters in the third stage, having moulted twice; about eight days old ; reared artificiully at Wickford, R. I.

Lobsters in the fourth stage, having moulted three times; about two weeks old; reared artificially at $W$ ickford, R. I.

Lobster in fifth and sixth stages; reared at Wickford, R. I.

Lobsters in the seventh stage; reared at Wickford, R. I.

Lobster seven weeks old; reared at Wickford, R. I.

Lobsters reared at Wrckford, R. I.; larger specimen eighteen weeks old; smaller specimen about three weeks old.

Lobsters reared at Wickford, R. I.; both specimens nineteen weeks old; reared under the same conditions.

Lobster five months old; reared at Wickford, R. I.

Three lobsters of the same age; about five and a half months old ; preserved October 20,1901 ; reared at Wickford, R. I.

Three lobsters of the same age, illustrating differences in the rate of growth; age about one year and three months.

\section{Specimens of adult lobsters illustrating spawning and gronoth :}

Male lobster.

Female lobster.

Female lobster with eggs.

Lobster which had burrowed about $2 \frac{1}{2}$ feet in the ground, midway between high and low tide; taken February 4, 1904.

A claw from a recently moulted lobster, together with the old east.

Four casts of lobsters.

Lobsters taken from stomach of codfish.

A regenerated claw with the cast in which it developed, taken from a lobster which was in the process of moulting.

\section{Microscopic preparations of lobsters :}

Lobster in the "first stage," recently hatched; magnified 1,000 diameters.

Lobster in the "second stage," about five days after hatching; shell has been shed once ; magnified 1,000 diameters.

Lobster in the "third stage," about ten days after hatching; shell has been shed twice; magnified 1,000 diameters.

Lobster in the "fourth stage," about two weeks after hatching; shell has been shed three times; at this stage the lobster changes the swimming life for life on the bottom; magnified 1,000 diameters.

Lobster of the "third stage," showing parasitic growths, diatoms and stalked protozoa; magnified 1,000 diameters.

Peridinium or Gymnodinium, which occurs in such quantities in Narragansett Bay as to constitute a plague, killing thousands of barrels of shell fish and fishes. 


\section{Development of a Trout.}

\section{Models illustrating the early stages of development of a trout:}

The fertilized egg is shown in model 1. The white portion represents the disk of protoplasm which, by its growth and development, gives rise to the embryo. The yellow portion, which is relatively large in the early stages, is the yolk, which selves as food, and is gradually absorbed during the process of development. The first marked change is the formation of a furrow which divides the protoplasm into two masses or blastomeres, as showu in model 2. Each of these becomes divided by a cross furrow, producing 4 cells, as shown in model 3 , and subsequent divisions give rise to $8,16,32$, and, eventually, numerous cells, as shown in models 4-8. During the later stages of this process the protoplasmic matter has increased by the absorption of some of the yolk, which becomes thereby relatively and actually smaller. The mass of cells has become lens-shaped, its lower surface dipping somewhat into the yolk, as shown in models 9 and 10, which represent sections of about the stages shown in models 6 and 7 , respectively.

The mass of cells which has before been uniform now becomes differentiated into two layers, and a cavity appears between the lower layer and the yolk. This is shown in models 11 and 12, where the layers are indicated by conventional colors. Soon after, a third layer appears between these two, as shown in model 13 . These three layers give rise to all the tissues of the adult fish, in general terms the outer giving rise to the outer skin, brain, and sense organs, the inuer or lower layer to the lining of the alimentary canal and to parts of the related organs, and the middle layer to the bones, muscles, blood vessels, etc.

As the protoplasmic portion or blastodermic disk gradually extends over the yolk its edge becomes thickened and the body of the fish begins as a tongue-like growth inward from a part of this ring, gradually extending over the disk, as shown in morlels 14-21. The thickened folds shown in model 21 and several of its predecessors represent the developing brain and spinal cord.

Subsequently the sense organs, alimentary canal, and other orgass appear, the bead and tail of the embryo grow free from the now inclosed dwindling yolk, and at the time of hatching the latter remains as a protuberant sac on the belly, furnishing nourishment to the fry until such time as it is able to take food through its mouth.

\section{Bacteria and Fish Pathology.}

\section{('ultures of bacteria from woter and from the diseases of fishes:}

This exbibit is designed to illustrate the Commission's work in a comparatively new field. Bacteria are of chief importance in human disease, and it was to be anticipated that they would play a corresponding part in lower forms. Some important affections of fisbes have been trace 3 to bacterial infection, and several of the cultures shown were made from the blood or tissues of diseased fishes. Notable among these are the bacillus of tuberculosis in fishes, from a European source, this disease not having yet appeared among fishes in this country, and Bacterium trutta, a chromogenic organism which recent investigations of the Commission show to be the specific cause of a destructive disease of the brook trout.

The principal pus cocci are also represented, among which the streptococcus is most important, causing the "oyster hand," familiar in oyster regions, and arising from wounds caused by "shucking" oysters or handling the shells.

A number of salt and fresh water bacteria are shown, including some handsome chromogens. Some of these are also frequently found unassociated with water. The commoner water organisms may be frequently obtained from tissues or regions of fishes to which they have access.

The cultures as exhibited are not living, the growth haring been killed and the medium upon which it rests hardened by formalin.

Bacillus coli. The common "colon" bacillus ; present in sewage and contaminated water. Cultures on gelatine and potato.

Bacillus pyocyaneus. A pathogenic bacillus, the cause of " blue pus" ; occasional in water. Cultures on agar and potato.

Bacillus prodigiosus. Occasional in water. Cultures on agar aud potato.

Bacillus cloaca. Common in some river waters. Cultures on agar and potato.

Bacillus subtilis. The very common "hay bacillus," found nearly everywhere. Cultures on agar and potato.

Bacillus violaceus. A violet color producing organism, found in river waters. Cultures on agar and potato. 
Bacillus vulgaris. Causes putrefaction; also a disease in fishes. Widely distributed. Cultures on gelatin and potato.

Bacillus tuberculesis piscium. The bacillus producing tuberculosis in fishes. Cultures on glycerin agar and glycerin potato.

Bacterium truttce. A chromogenic organism, the specific cause of a destructive disease in brook tront. Cultures in agar and bouillon.

Bacterium mycoides. A common water organism; from the Potomac river at Washington. Cultures on agar and potato.

Streptococcus pyogenes. An important and well known pathogen; found in abscesses in fishes, and the cause of the so-called "oyster hand," a suppurating infection of wounds received in handling oysters. Cultures on agar and gelatin.

Staphylococcus pyogenes aureus. Found in abscesses in fishes, and largely concerned in suppuration in general; found in water and widely distributed. Cultures on agar and potato.

Sarcina luten. Harmless spherical bacteria, frequently present in water. Cultures on agar and potato.

Plates illustrating some diseases and abnormalities of fishes:

Both wild and domesticated fishes are subject to parasitism and disease which sometimes cause among them extensive and fatal epidemics, or are the normal phenomena which terminate the life of the adults of certain species after spawning, as in the Pacific salmons of the genus Oncorlynchus, but in most cases they are sporadic and rarely fatal.

Owing to the erowding of the young in ponds, troughs and other circumscribed waters, disease is more common and more fatal among fishes raised in captivity than among those living in a state of nature, and malformatious resulting from injury to the eggs and young are more frequently observed, if not of more frequent occurrence. The epidemics are usually due to bacteria, fungi and low animal forms, but sometimes great mortality arises from purely mechanical and chemical causes, notably from a deficiency or a superabundance of air in water.

The following plates are exhibited to illustrate a few of the diseases observed in wild and domesticated fishes:

Infectious disease in trout: Brook trout (Salvelinus fontinalis), showing the blood extravasations and ulcers caused by Bacterium trutto. This disease is very destructive to domesticated trout, but is harmless to man.

Animal parasites of trout: Copepods, crustacean parasites, upon the gills of brook trout. Occasional and seldom fatal.

Tumor: A tumorous growth protruding from the gills of a rainbow trout (Salmo irideus). Occasional among domesticated trout; causes anemia and is usually fatal. The specimen illustrated is from the government hatcheries of New Zealand.

Short gill covers: A malformation of the brook trout (Salvelinus fontinalis) exposing the gills. Caused by domestication and unknown among wild fish. Seldom fatal.

Deformities among domesticated fishes: An adult brook trout (Salvelinus fontinalis), natural size, deformed by mechanical injuries received probably before hatching.

Deformities among wild fishes: Young menhaden (Brevoortia tyrannus) with curvatures of the spine, caused by injuries or" concussions during incubation of the egg.

The gas disease: "Popeye" in the scup (Stenotomus chrysops). A symptom of the gas disease caused by an excess of dissolved air in the water. Gas has accumulated behind the eyeball.

Pacific salmon during the spawning season: A male humpbacked salmon (Oncorhynchus gorbuscha) dying after the spawning season. Frayed fins, fungus patches, and fungus ulcers. The Pacific salmon spawn but once, and then die a natural death. The injuries and fungus attacks are incidents of and not the cause of death. For canning purposes salmon are taken long before this stage.

Pacific salmon during the spawning season: A male redfish or blueback salmon (Oncorhynchus nerka) after spawning. Frayed fins and fungus patches.

\section{Maps, Charts, and Illustrations.}

Fourteen charts to illustrate the geographical distribution of the important food fishes of the Mississippi Valley, as follows: 
Common buffalo-fish (Ictiobus cyorinella).

Small-mouthed buffalo-fish (Tetiobus bubalus).

Common sucker (Catostomus commersonii).

Channel cat-fish (Tctolurus punctatus).

Chuckle-head cat-fisb (1ctalurus furcatus).

Yellow cat-fish (Leptops olivaris).

Shovel-nosed sturgeon (Scrphorhynchus platorhynchus).

Spoon-bill cat-fish (Polyodon spathula).

Crappie (Pomoxis annularis).

Blue-gill sun-tish (Tepomis pallidus).

Small-mouth black bass (Hicropterus dolomieu).

Large-mouth black bass (Micropterus salmoides).

Yellow perch (Perca flavescens).

Fresh-water drum (Aplodinotus grunniens).

One frame of plates from U. S. Fish Commission publications illustrating the embryology of the common lobster, Homarus americanus.

Three frames of colored plates of fishes of Porto Rico, from publications of the U. S. Fish Commission.

Two swinging sereens of colored aud plain plates of fishes of Hawaian Islands. from publicatious of U. S. Fish Commission.

\section{APPARATUS, METHODS AND STATISTICS OF THE FISHERIES.}

\section{Model Illustrating Fishing Scenes on the New England Coast.}

This model represents the five important methods employed in the capture of fish and lobsters for commercial purposes by fishing vessels along the New England const.

The gill net, set at the surface, is used for catching mackerel, herring, and other fish that school on the surface. The mesh of the net varies in size from $2 \frac{1}{3}$ to $3 \frac{1}{2}$ inches, and the vessel carries, on an average, ten nets to each member of the clew.

At the rear of the gill-net set at the surface is a trawl; this varies in length and has short lines with hooks fastened to it at regular intervals, the.intervals varying from 3 to 15 feet, according to the fishery in which the line is used. In the haddock fishery the hooks are 3 feet apart; in the halibut, 12 to 15 feet. The trawl is set by allowing it to sink to the bottom, the ends being secured by anchors, from which long lines lead to the surface, where they are attached to buoys or kegs, so that the fishermen can locate the trawl. Each line of trawls is about 50 fathoms long and each member of the erew has from 21 to 50 lines to fish, or from 1,500 to 3,000 hooks. Cod, haddock, halibut, and pollock are the principal fishes caught by this method.

The purse seine is principally used for capturing mackerel, herring, and menhaden. The average mackerel purse seine is about 225 fathoms aud 1,000 meshes deep (2-inch mesh), and costs from $\$ 500$ to $\$ 800$. It is set around a school of fish so as to form a bag or purse, as shown by model.

The net set on the bottom illustrates the use of the gill net in catching cod, which school near the bottom of the ocean. 'The fish are caught by passing their heads through the meshes of the net.

The lobster traps are set on the bottom and show the method of catching lobsters. In the background is 'Thatcher's light-house, north of Cape Ann.

\section{U. S. Fish Commission Schooner Grampus (rigged model; scale, $\frac{1}{2}$ inch to 1 foot).}

The Grampus was designed by and built under the supervision of Capt. J. W. Collins, U. S. Fish Commission. She was launched in the spring of 1886, and went into commission on June 5 of that year. She is provided with a well, located in the middle of the vessel, in which fish and other marine animals can be kept alive and taken from distant fishing-grounds to the coast stations of the Commission for fishcultural purposes or to serve as objects of study and research for biologists. In other important respects she is arranged and fitted to adapt her to carrying on the marine researches and investigations which are being continuously prosecuted by the Commission. Among other things, she has been fitted to operate a beam-trawl, to test its utility, in a commercial way, in American waters.

The Grampus is a two-nasted, schooner-rigged vessel, 90 feet long over all ; 81 feet 6 inches L. W. L.; 22 feet 3 inches beam, and 10 feet depth of hold. She registers 83.30 tons. An important object sought in her design was the production of a new type of fishing vessel-one that will be much safer and in various ways better adapted to successfully encounter the exigencies which must be met by schooners employed in the ocean fisheries. In model and rig she is a radical departure from the vessels commonly engaged in the New England fisheries prior to her advent, and ber superiority in safety, speed, and other desirable qualities has been fully establisbed. After 
twelve years' service the Grampus is unexcelled in speed by fishing vessels or pilot boats. She differ's from the typical fishing schooner of the time when she was built in being 18 to 24 inches deeper, in having 6 to 10 inches less beam, and an easier after section. She has less proportional width aft, greater rake to stern, and pilot-boat bow, with strait stem above water. Her extreme draft is $11 \frac{1}{2}$ feet.

The principal features of the Grampus have been copied by New England builders. Nearly all of the fishing vessels recently bult are deeper than formerly, and embody other featmies that characterize the Grimpus. The spirit of improvement has received such an impetus that the best skill of the most eminent naval architects has of late been devoted to designing fishing vessels.

\section{Models of Fishing Vessels and Boats.}

New Englund mackerel seining schooner (rigged model : scale, $\frac{1}{2}$ inch to 1 foot) :

The schooner Senator Gardner', of Gloucester, Mass., was built in Essex, Mass.. in 1900, for employment in the summer mackerel fishery and in the winter frozen-herring tracle; is a vessel of modern type, suitable for all branches of the fisheries, and is represented in the model all ready to start on a cruise, seine boat on deck and seine stowed on deck, ready to be taken into boat on arrival at the fishing-grounds.

Length over all. 114 feet; water-line length, 92 feet; beam. 25 feet; depth. 11 feet 6 inches; gross tonnage, 135 ; bowsprit, outboard, 30 feet; foremast from deck, 65 feet; foretopmast, 42 feet; mainmast, 70 feet from deck; maintopmast, 44 feet ; mainboom, 67 feet; maingaff, 37 feet; foreboom, 31 feet; foregaff, 32 feet; jumbo-boom, 27 feet; seine boat, 40 feet long over all by 8 feet 6 inches beam.

\section{New Fingland market fishing schooner (rigged model: scale, $\frac{1}{2}$ inch to 1 foot) :}

The schooner Rob Roy, of Gloncester, Mass., was bnilt at Essex, Mass., in 1900, for employment in the market fishery, and is an entirely new model in fishing vessels, called the "knock-about" type. She is an ideal market fishing craft, as she is easily handled aronnd the dories when out setting or hauling trawls, and is a smart sailer and an excellent sea boat. The model represents a market fisherman as she appears ready to go to sea; dories on deck, nested right side up.

Length over all, 110 feet; water-line length, 88 feet; beam, 23 feet 6 inches; depth, 11 feet; bowsprit, outboard, 26 feet; foremast, 58 feet from deck; foretopmast 37 feet ; foreboom, 28 feet ; foregaff, 27 feet: mainmast, 71 feet from deck ; maintopmast, 41 feet; mainboom, 66 feet; maingaff, 36 feet.

Designed by B. B. Crowninshield, Boston, Mass.

Neso England Grand Bank Schnoner (rigged model : scale, $\frac{1}{2}$ iuch to 1 foot) :

The schooner John J. Flaherty, of Gloucester. Mass., was built at Essex, Mass., in 1899, for Grand Bank cod fishing in summer and in the winter frozen-herring trade. The model represents a fast and seaworthy vessel, ready to go to the Banks on a cruise. She is under full sail, with dories turned up and secured on deck, and checkerboard and oil butts in place. She illustrates the extreme type of Grand Banker, and is a very easy vessel to anchor in a heavy sea. Carries 2,200 barrels of herring, and had 600,000 pounds of cod on her first Grand Bank trip.

Length, over all, 122 feet; water-line length, 102 feet; beam, 25 feet 6 inches; depth, $12 \frac{1}{2}$ feet ; gross tonnage, 166.35 ; bowsprit, outboard, 36 feet ; foremast, 64 feet from deck ; foretopmast, 39 feet ; foreboom, 33 feet ; foregaff, 34 feet ; mainmast, 76 feet; maintopmast, 44 feet; mainboom, 70 feet; maingaff, 40 feet; jumbo boom, 28 feet.

Designed by Lawrence Jensen, Gloucester, Mass.

Chesapeake Bay oyster pungy (rigged model : scale, $\frac{1}{2}$ inch to 1 foot):

The schooner W. F. MeKeven, of which this is a miniature, is a typical oyster pungy of the Chesapeake Bay region, where hundreds of such vessels are employed. She was built in 1865, and was engaged in dredging oyster's for many years. This type of fishing vessel has undergone little change in half a century.

A carvel-built, wooden, keel vessel, with moderately sharp, flaring bow, curved, strongly raking stem, long head, sharp floor, long, lean run, shallow, square stern, raking sternpost, flush deck, log rail except aft of main rigging where there is an open quarter rail, rollers on rail amidships for dredge rope to pass over, typical schooner rig. Model equipped with oyster dredges, winches, etc.

Length, over all, 68 feet; beam, 20 feet 9 inches; depth, 7 feet.

The builders at Baltimore and other ports on the Chesapeake began the construction of sharp vessels much earlier than elsewhere on the Atlantic coast, and oyster pungies substantially like those used in the closing years of the nineteenth century 
were built as early as 1845 or 1850 . Almost without exception these are keel vessels, with tall, raking masts, long bowsprit, and higb, narrow sails. They are swift, and quick in stays.

\section{New Orleans fishing lugger (rigged model: scale, 1 inch to 1 foot):}

Model of the typical lug-rigged boat, so extensively used in the fisheries from New Orleans and vicinity by fishermen who are chiefly Italians or other natives of sonthern Europe. This represents a carvel-built, center-board boat, half deck forward, with wide washboards and high combing around the elliptical-sbaped cockpit, the latter being fitted witl hatches at cover, about two-thirds of its length from the forward part. There is a cuddy forward, which is entered through an opening in front of the mast. 'The boat has a graceful sheer, increased forward to a bow shape; a sharp bow, with concave water line and straight stem; very shallow keel ; moderately rising floor, with quick turn to bilge; medium length of run; V-shaped, square stern. with no overhang to counter ; rudder hung outside and moved by tiller. The rig consists of a single mast, 12 feet abaft the stem, and on this is set a single large lug-sail, which tacks to a traveler near the bow, where the sheave trims to an iron traveler across the taffrail or at the stern. The sail is not dipped in making short tacks to windward. Boats of this class are not used anywhere in the United States except on the Gulf coast, and are restricted there chiefly to Louisiana. They are celebrated for speed, and are reputed to be especially well adapted to the shallow, narrow waters in which they have to work.

Length, over all, 40 feet 6 inches; length of water line, 39 feet 9 inches; beam, 12 feet 6 inches; depth, amidsuips, keel to top of gunwale, 4 feet 9 inches; draft, aft, 2 feet 9 inches; forward, 1 foot 9 inches; length of mast, extreme, 45 feet; length of yard, 38 feet 6 inches.

Key West smackee (rigged model: scale, 1 inch to 1 foot):

The welled fishing boat Jeff Brown, of Key West, Fla., of which this is a miniature, was built for the market fishery at that port in 1883 . Boats of this kind are called "smackees," a variation of the term "smack" as applied to welled vessels. They are employed in considerable numbers at Key West, and are noticeable for having the "Mudian rig"-a leg-of-mutton mainsail and jib-and also a well in which the fish are kept alive.

A wooden, carvel-built, sloop-rigged keel-boat, with good sheer; sharp bow, rising floor, long run and skag; V-shaped, raking stern; cockpit aft ; well amidshius, cuddy hatch forward; mast stepped well forward; short bowsprit. Length over all, 24 feet; beam, 8 feet 3 inches; molded depth, 3 feet ; mast, above deck, 32 feet; bowsprit, outside, 6 feet; main boom, 23 feet.

The majority of the Key West smackees are slightly smaller than the Jeff Bronon, and differ from the latter in having square vertical sterns, with their rudders hung outside. They sail well and are reputed to be seaworthy and able in strong winds.

Connecticut oyster steamer (rigged model: scale, $\frac{1}{2}$ inch to 1 foot):

Model of the oyster steamer Jeremiah Smith, of New Haven, Conn. This vessel was built in 1885, at West Haven, Conn., and is one of the largest and finest vessels of this class, constructed for the special purpose of carrying on the oyster fishery in Long Island Sound. The model is fitted with boats, dredges, etc. This vessel is wide and rather flat, with moderately sharp bow and low, rounding bilge; rather short run; large deck houses; provided with rollers for operating the dredge; side chafing chocks, etc. The wheelhouse is above the main-deck house. The ressel is fitted with a screw propeller, and will steam about 7 or 8 knots.

Gross tonnage, 113.38; net tonnage, 66.68 ; length over all, 72 feet; extreme beam, 24 feet; draft, 6 feet.

\section{Market steamer Golden Gate (rigged model : scale, $\frac{1}{2}$ inch to 1 foot):}

The Golden Gate was built in 1891 for employment in the market fishery from San Francisco, Cal. It is a representative of the type of small steamers of which several have been built to fish from San Francisco with the parenzella. The building of such vessels for the market fisheries of the Pacific coast was suggested by the U. S. Fish Commission in an article published in 1888, entitled "Suggestions for the employment of improved types of vessels in the market fisheries," etc. Sharp bow ; straight stem above water line, curved below; moderate rise to floor ; long, lean run; round stern; strong sheer ; engine and pilot houses on deck; sloop.rigged, with loosefooted gaff mainsail, 
Length, over all, 80 feet; beam, 18 feet; depth, 7 feet; mast, deck to truck, 60 feet; gaff, 20 feet; mainsail, on foot, 62 feet; luff, 36 feet; head, 18 feet 6 inches; leach, 59 feet; jib: luff, 47 feet; leach, 45 feet; foot, 15 feet.

Steam schooner Royal (rigged model : scale $\frac{1}{2}$ inch to 1 foot):

'The schooner Royai was built at Benicia, Cal., in 1891, and is owned at San Francisco. She is a representative of the type of small auxiliary steam schooners employed in the Alaskan salmon fishery, and is noticeable for having pole masts and a leg-of-mutton mainsail, which are charucteristies of schoowers fishing in Alaskan waters. Long, sharp bow; raking, curved stem; rising floor; medium length of run; overhanging, elliptical stern; good sheer ; fitted with deck houses; serew propeller, and rigged as a two-masted schooner.

Leugth, over all, 81 feet; tonnage length, 75 feet; beam, 20.6 feet; depth, 8.2 feet; net tonnage, 29.54 ; nominal horsepower, 20 ; mainmast, deck to truck, 56 feet ; foremast, deck to truck, 56 feet; bowsprit, outboard, 13 feet; main boom, 44 feet ; foregaff, 16 feet.

\section{New England Dory:}

Fully equipped model, with trawl lines, tubs, anchors, oars, etc., for the Bank cod fishery. Similar boats are employed in the halibut, shore cod, market, and other tisheries. Each vessel carries 3 to 9 dories and 1 or 2 men go in each dory.

\section{Croatan Sound fishing bout (rigged model : scale, 1 inch to 1 foot):}

Sloop boats of this type are used in large numbers in the gill-net shad fishery of Croatan Sound and adjacent waters in North Carolina. Many of them are built on Croatan Island. They are well adapted to the shad fishery, being fine sailers and easy to row. This is a wooden, carvel-built, open, centerboard boat; long, sbarp bow; rising floor; long, fine run; raking $V$-sbaped stern; good shear; a single mast; loose-footed, sprit mainsail and jib, the latter tacking down to the stem head.

Length, over all, 23 feet 6 inches; beam, 7 feet; depth, top of guuwale to keol, amidships, 2 feet 6 inches; mast above thwart.

\section{Pound-net boat :}

Used on Great Lakes in lifting pound and trap nets.

\section{Irish drop net:}

Nets, Traps, Pots, etc.

This net is used by the Irish fishermen in Boston and other New England towns in capturing perch for the fresh-fish market.

Snap net: Used for eatching cunners on the New England coast.

Crab net: Used for catching crabs.

Terrapin net: Used on the Pacific coast.

Cost net: $4 \frac{1}{2}$ feet, $\frac{5}{8}$-inch mesh, mounted.

Used on Atlantic coast, chiefly for catching shrimp, though also for fishes.

Cast net: $4 \frac{1}{2}$ feet, $1 \frac{1}{4}$ mesh, mounted.

Bag seine (model):

Very generally used throughout the country for fishing in shallow water, for taking shrimp, herring, mackerel, shad, and for general river fishing.

River seine (model):

Used in great variety of sizes for inland river and fresh-water fishing.

Purse seine (model):

This represents the style of purse seine in general use on the Atlantic coast and Gulf of Mexico for taking mackerel and menhaden. They are made in lengths from 180 to 250 fathoms and from 8 to 20 fathoms deep. For mackerel the mesh is commonly $1 \frac{7}{8}$ or 2 inches, and for menhaden a larger variety is used, running from $1 \frac{3}{4}$ to $2 \frac{3}{4}$ inches. They are made of a light cotton twine, graded from a very small size on the ends to a heavier and a stronger size in bunt.

\section{Minnoro seine:}

For taking bait, small fish, etc. Mesh one-half inch. Loaned by the American Net and Twine Company, Boston. 


\section{Capelin seine (model):}

Used in Nova Scotia, New Brunswick, Labrador, and Newfoundland fisheries; 20 to 75 fathoms long and 2 to 8 fathoms deep. The mesh is graduated from three-fourths inch in bunc to 2 inches on end of arms. When launce are to be taken a three-eighthsinch mesh bunt is put into the centel of the seine.

\section{Cod seirie (model):}

Used in Nova Scotia, New Brunswick, Labrador, and Newfoundland fisheries; 100 to 130 fathoms long and 10 to 15 fathoms deep. The mesh is 3 inches in bunt, and on

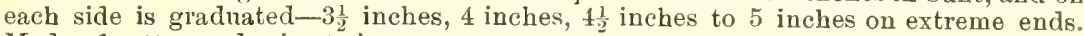
Made of cotton cod-seine twime.

\section{Herring seine (model):}

Used in British North American and Newfoundland fisheries; 50 to 150 fathoms long and 4 to 10 fathoms deep. The bunts are generally made of $1 \frac{1}{2}$ - or $1 \frac{3}{4}$-inch mesh, and the arms of 2 -inch mesh. Made of cotton herring-seine twine.

\section{Cod trap (model):}

Used principally on the Newfoundland and Labrador coast; 8 to 16 fathoms square and 8 to 12 fathoms deep. The pot is made of 4-inch mesh and the leader of 5 - to 6 inch mesh. Made of cotton trap twine.

\section{Lrike Erie pound net (model):}

Used on the Great Lakes for taking white-fish, trout, saugers, etc. Pots are from 30 to 45 feet square and from 30 to 60 feet deep; hearts 108 feet long; pots are of $2 \frac{1}{1}$. inch mesh, hearts are $3 \frac{1}{2}$-inch mesh, and leaders are of 5 - to 6-inch mesh. Made of cotton trap twine.

\section{Bass trap (model):}

Used for taking bass, scup, flounders, and other fish on North Atlantic coast. Crib or pot is from 20 to 30 feet square and 20 to 30 feet deep. Crib, $2 \frac{1}{2}$-inch mesh. Small hearts, $2 \frac{1}{2}$-inch mesh; large hearts, 3-inch mesh. Leader, 5-inch mesh.

\section{Rose floating trap (model):}

Used on Rhode Island coast for scup aud bass; 30 to 50 fathoms loug by 10 to 25 fathoms wide and 8 to 14 fathoms deep. The mesh in head end of trap is 3 inches to $3 \frac{1}{2}$ inches, and in front end $4 \frac{1}{2}$ to $5 \frac{1}{2}$ inches. Leaders about $5 \frac{1}{2}$-inch mesh.

\section{Heart trap or weir (model):}

Used on the Atlantic coast for taking herring, mackerel, blue-fish, cod, etc. Bowl 96 feet across and from 25 to 50 feet deep. Rim, $1 \frac{3}{4}$-inch mesh. Hearts, 240 feet long. 4-inch mesh. Leaders, 6- to 12-inch mesh, and made of cotton trap twine.

Small fyke: For taking cat-fish and other fresh-water fish in rivers and ponds.

Eel fyke: Used for taking eels in creeks and rivers emptying into the sea.

Small flounder fyke: Used in taking flounders along the Atlantic coast.

\section{Blue-fish gill net (model):}

Made in great variety of sizes, from 50 yards to 200 yards long and from 4 to 12 yards deep. The mesh varies for different localities from 4 to 6 inches.

\section{Shad drift gill net (model):}

Made in a very great variety of lengths to suit the place where they are to be used, from 40 to 50 meshes deep. Twine used is No. 30 to No. 40-2 and 3 cord linen. When these nets are set stationary on stakes no floats are used and very few sinkers.

\section{Salmon gill net (model) :}

Used on the Columbia river and wade in different lengths, a common length being 150 fathoms. They are 33 meshes deep and $9 \frac{3}{4}$-inch mesh, of No. $40-12$ or 13 ply linen, and 60 meshes deep of $7 \frac{1}{4}$-inch mesh, No. $40-8$ and 9 ply linen. On Frazer river they are used 40 meshes deep of $5 \frac{7}{8}$-inch mesh of 4 and 5 ply linen. 


\section{Herring gill nets (model):}

A variety of sizes for different localities, from 20 to 75 fathoms long and 110 to 250 meshes deep, of $2 \frac{1}{4}$ to $3 \frac{1}{4}$ inch mesh, of cotton gill-net twine.

\section{Cod gill net (model):}

Used on the New England coast and made 75 yards long, 18 meshes deep, $8 \frac{1}{2}$ to $9 \frac{1}{2}$ inch mesh, of medium-laid cotton twine. Glass balls are used for floats and bricks for sinkers.

Shad gill net: Completely rigged, 5-inch mesh, 100 feet loug.

White-fish gill net: Completely rigged, ordinary sized mesh, 100 feet loug.

Sturgeon net: Ordinary sized mesh, completely rigged, 100 feet long.

Cod gill net: Completely rigged, usual sized mesh, 100 feet long.

Salmon gill net: Completely rigged, usinal sized mesh, 100 feet loug.

\section{Herring gill net:}

Made in a variety of sizes for different localities, ranging from 20 to 75 fathoms long and from 110 to 250 meshes deep, of $2 \frac{1}{4}$ to $3 \frac{1}{4}$ inch mesh, of cotton gill-net twine. Mackerel gill nets are made in practically the same style mesh, $2 \frac{3}{4}$ to $3 \frac{3}{4}$ inch.

\section{Tinen dip nets :}

Used for capture of minnows, shrimp, etc. Sizes vary from 12 to 36 inches.

\section{Cotton dip nets:}

Used for the capture of minnows, shrimp, etc.

\section{Eel. pot.}

\section{Wire eel pot:}

Used by fishermen in Waquoit Bay, Massachusetts, in fishing in waters 6 to 9 feet deep. Live minnows are considered the best bait. When live bait cannot be obtained, fresh fish of any kind is used. The fish is suspended in the middle of the pot by a string fastened to the "backbone" which runs lengthwise of the pot.

\section{Wicker eel pot:}

Used by fishermen at Vineyard Haven, Mass., and fished in water 8 to 21 feet deep. Ballast of stones sufficient to sink the pot is used, the stones being put into both eompartments. The bait is not suspended, but lies on the bottom of the pot.

Another pot made exactly like this, only from 5 to 7 feet long, is used in water 2 or 3 feet deep, generally in a narrow creek. No bait is needed with this pot, but a leader and wings, made of sticks about 15 or 18 inches long and woven with rope, is used. The leader is usually 20 to 40 feet long and each of the wings is about 20 feet long. The pot when set as above really becomes a small weir.

\section{Lobster pot (rounded top):}

This style pot has been in common use in southern Massachusetts a number of years and is known as a "parlor pot." The style is peculiar (in having one end closed) to the territory south of Cape Cod. The pots used north of Cape Cod have a funnel in both ends, so that it is possible for a lobster to enter through either end. The fishermen claim that the parlor pot is preferable, as many are lost through the lower end of the double-end pot while it is being hauled to the surface. All the lobster pots require ballast to sink them to the bottom. The average ballast per pot consists of 8 bricks placed on the bottom of the pot and along the sides, and held in place by laths along the sides tied with a string. This pot is fished in water varying in depth from 10 to 200 feet. Fresh fish is considered the best bait, but when this cannot be obtaiued salt bait is used.

\section{Lobster pot (flat top):}

This is practically the same as the other lobster pot, differing only in shape. Fishermen agree that these pots fish equally well, but are gradually discarding the rounded top for the flat top, as the latter store better in a boat when being carried to and: from the fishing grounds. 
Lobster pot (Cohasset).

\section{Lobster trap:}

This trap is made of slats and twine and is in more general use for capturing lobsters than any other form on the Atlantic coast.

Eel pot: Used in the captnre of eels on the New Englaud coast.

Dip net.

\section{Madel of Columbia River Stationary Fish Wheel.}

These wheels are used along the Columbia river from the falls at Celilo to a point as far downstream as Corbett's Lauding, Oregon. They are of two kinds--stationary wheels like the model, and scow wheels. The latter are monnted on stout scows, from which they are hung downstream by the aid of strong derricks or arms. The operation of the two kinds of wheeld is the same, except that the scow wheels are towed from point to point ind anchored in places which seem favorable.

The wheels are usually placed where the shore juts ont into the river, for at such points the chanuel and current are most favorable to the ascent of the fish. In addition to placing the wheels on the points, they are placed in the gorges, where the river is narrow and swift. When the salunon come into contact with the leads to the wheel they follow the lead until they reach the wheel, where they are attracted by the large volnme of water which comes through. One "nib" of the wheel is constantly in the water, and as the salmon swim up into it they are lifted from the water, and as the wheel turns are throwu toward its axis, near which is placed a chute, and down this they slide into the fish box or well.

The only attention that the wheels require is that they be guarded against drift; that they be raised or lowered according to the rise and fall in the river, and that the fish be taken from the well.

The swift water in which the wheels usually work, especially if the drift be bad, is hard on them, and they usually undergo extensive repairs every year. The wheel from which the model was built is sitnated just opposite Cascade Locks, on the Washington shore of the Columbia river. The cost of such a wheel is approximately $\$ 8,000$. The photographs show the original wheel and location, while the accompanying plan shows a stretch of the Columbia river.

The winches on the model are used for lifting the trap to the fish well, lifting the boxes of fish from the well, raising and lowering the wheel, etc.

These wheels at favorable times catch as many as 28 tons of salmon per day.

The dimensions of the original wheel are as follows: Height of gins, 95 feet; diameter of wheel, 52 feet; width of wheel, 8 feet; length of crib, 50 feet; width of crib, 45 feet; height of crib, 44 feet; length of lead from crib to shore, 80 feet; length of lead from crib toward river, about 40 feet.

\section{LiNes.}

Tub of deep-water or Grand Bank cod trawl, with auchor, buoy, black ball, and staff.

Tub of inshore cod trawl, including anchor, buoy, black ball, and staff.

Tub of haddock trawl, including anchor, buoy, black ball, and staff.

Skate of halibut trawl, including anchor, buoy, black ball, and staff.

Georges Bank cod haud line in tub, complete.

Nantucket Shoals or Rip cod hand line.

Pollock hand line. This hand line is used by fishermen from the deck of a ressel for capturing pollock in inshore waters.

Mackerel line and jig, nsed in jigging for mackerel.

Blue-snapper line. Used in mackerel fishery with a plain hook instead of jig.

Squid line with jig attached. Used in eatching squid for bait.

Smelt spreader with smelt hooks.

Pacific coast trawl line. Used for catching rock-fish, halibut, flouuders, and other fishes, from Cape Flattery to San Diego.

\section{Sturgeon set line:}

These lines are usually a mile or two in length, aud are made to carry upward of a thousand hooks. They are used on the upper' St. Lawrence and eastern end of Lake Ontario for catching sturgeou. 
Oyster dredge:

Appliances for Dredgring and Seizing.

Galvanized-iron frame 34 inches wide across mouth, with net of iron mesh. This style of dredge is generally used all along the Atlantic coast, particularly in the Chesapeake Bay, on sailing vessels.

Oyster scrupe:

Galvanized-iron frame 34 inches wide across the month, with bag of cotton netting Used along the Atlantic coast of the United States on oyster beds in shoal water and soft bottom.

\section{Scallop dredge:}

In common use in Buzzards Bay and the waters south of Cape Cod, Mass. It is operated from a sailboat and is dragged along the bottom-while the boat is sailing, thus scooping up the scallops. After the dredge has been dragged for a short time it is bauled to the surface and the contents emptied into the boat.

\section{Clam or quahog rake:}

Used at Edgartown. Mass. When rigged it has a pole 20 to 30 feet long, so that the operator can cover considerable ground without changing the position of the boat from which he works. This pole is made of yellow pine and is 2 inches square at the end joining the rake, and gradually tapers to 1 inch in diameter at the end.

\section{Sec horse:}

Used at Edgartown, Mass., for digging clams which are covered with water. The canvas strap is passed over one shoulder and under the opposite arm, and enables the operator to exert considerable force with his back and shoulders in addition to that applied with his arms. The long teeth are forced down into the sand or mud and then the whole is lifted clear of the bottom; by a peculiar motion the mud and sand are then sifted through, the clams being retained above the teeth and brought to the surface.

Deep-zoater oyster tongs, used in water 30 to 200 feet deep.

Oyster tongs :

Galvanized-iron head and frame 24 inches wide with 14 iron teeth and shafts of wood 14 feet long. In common use along the Pacific coast by boatmen oystering in shallow water.

\section{Oyster tongs:}

Galvanized-iron head and frame 21 inches wide with 12 iron teeth and shafts of wood 12 feet long. In common use along the Atlantic coast by boatmen oystering in shallow water.

\section{Oyster nippers:}

Frame of galvanized iron 6 inches wide. Handle 6 feet 6 inches long. Used by tongers for catching single oysters in shallow water.

Clam fork: Used in digging clams on shore.

Clam hoe: Used in digging clams.

\section{Model of the Florida Sponge Fishery.}

The Florida ressel sponge fishery is prosecuted from small boats earrying two men, each vessel being equipped with from two to six boats. While the boat is managed and sculled by one man, the other, called the "hooker," watches the bottom through a glass-bottomed bucket, the "water glass," which is held with one hand while with the other he manipulates a long pole to which is attached a three-pronged hook. When a sponge is seen it is detached from the bottom with the hook and drawn to the surface. In the shallow water among the keys the water glass is seldom used and but one man goes in a boat, which he propels with the sponge pole. About fifty feet is the maximum depth at which sponges can be taken by means of "hooking."

The fresh sponges are killed by more or less prolonged exposure to the air and the fleshy parts are macerated out in enclosures called crawls. The sponge of commerce is merely the skeleton of the sponge animal.

The model shows the usual character of the bottom on which sponges are found and the various operations of catching and curing them. A sponge sale with a group of dealers is shown at the right. 


\section{Whaling Apparatus.}

Rocket-gun:

A stockless gun with a barrel of such shape and proportion as to balance on the shoulder of the gunner; designed to throw large rockets and shells; barrel, sheetcopper, eylindrical; two rods project behind the barrel and are fastened to an iron plate; barrel encircled with two wide transverse flanges, the lower one fixed, and the upper one hinged in such a manner that when the gunner is taking aim it lies parallel to the barrel, but is thrown up vertically by the action of the rocket to protect the gunner from the "backfire" of the rocket. The gun is discharged by firing the pistol throngh a hole made in the stock into the rocket.

Brand gun, No. 2 :

Barrel, cast-steel; front part of barrel round. Ramrod, hickory. Skeleton stock, iron. Guard-plate, steel. Kigid eye for lanyard. Patent bleech. Stock and barrel "browned." Length, 36 inches. Weight, $19 \frac{1}{2}$ pounds.

\section{Darting-gun :}

Pierce's darting gun. uld style, with pole, harpoon, and darting-bomb; mnzzleloading. Gun: Barrel, lock-case, socket for pole, socket-pieces or lugs for harpoon, and one forward guide for trigger, gun-metal; two after guides for trigger, brass ; bottom of lock-case, brass, soldered; firing-pin and trunnion, brass ; lock-case (cover for excluding moisture), leather with brass catch. Hammer concealed in lock-case, gun-metal. Trigger projecting beyond muzzle, steel rod. Harpoon, common toggleiron; rear end made to fit socket-pieces on the muzzle of the gun and provided with a projecting eye, in which the iron strap is made fast. Toggle branded "Macy" (manufacturer). Length of gun, 193 inches; length of pole, $56 \frac{1}{4}$ inches; length of trigger, 34 inches; length of narpoon, 30 inches; length of darting bomb, $15 \frac{1}{2}$ inches.

California gun-harpoon :

Head, common toggle, mortised, with flaring rear barb; shank, double; wire loop. served with twine; gun strap, whale-line. Length, 50 inches; length of toggle, $9 \frac{5}{8}$ inches.

\section{Allen's gun-harpoon:}

Four fixed barbs; shank in two sections; forward part wronght-iron, terminating in a socket, into which is fitted the rear part; provided with a fixed iron collar to be used as a "stop" for the iron strap. Rear portion of shank, wood with iron ferrule. Length, $46 \frac{1}{4}$ inches.

\section{Swivel gun-harpoon :}

Head, wrought iron, double-barbed; shank, malleable iron, cast; donble or slotted; loop with two eyes, wire, wrapped with wire; iron thimble attached, with rope for making fast the whale-line. Marked "S. Lydia." Length, 48 inches.

\section{Pierce's darting-gun harpoon:}

Head, common toggle, recessed, pivoted to end of shank; shank composed of two conjoined pieces of iron; forward end, rod-iron; rear portion, piping screwed into end of forward part; iron link, twisted, attached to middle of shank for iron-strap, whale-line; button, felt ; point of toggle, fractured. Length, $24 \frac{1}{2}$ inches.

\section{Explosive gun-lance :}

A kind of explosive lance, the record of which very little is known. Consists of two conjoined parts ; the forward half or magazine malleable iron, cast with the head, which has four cutting edges; the rear section, or fuse-shaft, cast iron, fluted on three sides for the ropes (which are placed in the gun with the lance) and attached to the bomb with a screw-joint. The rear extremity of the fluted elevations are perforated with three holes through which the strands of the rope are rove and braided. Time-fuse inclosed in fluted tubular shank. Cork shoe or button. Length, 33 inches.

Rifled whaling-gun :

Barrel, cast-steel, nine grooves; stock, walnut; rigid eye for lanyard. Length, 38 inches. Weight, 18 pounds. 


\section{Whaleman's swivel-gun:}

Barrel, stub-twist; stock, Saint Domingo mahogany; guide for taking aim, brass, extending along and screwed to barrel; elevated at rear end. Barrel fasteued to stock by bolts and lugs. Breech-plug chambered and screwed into the barrel. Two nipples. Flash-pan, brass, hinged to rear of elevated sight; barrel stamped "W. Greener, maker, Birmingham, 1853." Length, 51 inches. Weight, 56 pounds.

\section{Brown's whaling-gun:}

Stock, barrel, and guard-plate, gun-metal; trigger-guard fastened to stock with three screws; rigid eye on trigger-guard for lanyard; front and rear sights; breech-plug cast with stock; stock recessed for two nipples; stock and barrel connected by a screwjoint; muzzle reinforced with a gun-metal band. Stamped "Robert Brown, New London, Conn." Length, 46 inches. Weight, 36 pounds.

\section{Brand gun, No. 1:}

Barrel, cast-steel ; front part of barrel round. Elongated thimble for ramrod. Ramrod, hickory, with brass thimble and screw. Skeleton stock, iron, screwed to barrel. Guard-plate, steel. Rigid eye for lanyard. Lanyard attached. Stock and barrel "blued." Length, 38 inches. Weight, 23 pouuds.

\section{Shoulder-gun, with brass stock:}

Barrel, cast-steel, octagonal. Rear and front sights. Two thimbles for ramrod. Pamrod, hickory, with brass thimble and double worm-serew. Under side of barrel grooved for ramrod. Stock. gun-metal, cast with breech-plug and rigid eve for lanyard. Grip wrapped with marline. Lock, common percussion. Length, $35 \frac{1}{2}$ inches. Weight, 28 pounds.

\section{Breech-loading whaling-gun:}

Skeleton stock, cast-iron, painted black. Stock and breech-piece cast in one piece, with a small rigid eye at rear guard-plate for lanyard; barrel, steel, reinforced and screwed to the stock; breechblock, containing firing-pin, hinged to stock, and, when closed, beld by a snap-spring; central-fire cartridge. Length, 33 inches. Weigbt, 27 pounds.

\section{The Cunningham darting-gun:}

Breech-loading hinge-gun, with harpoon, strap, and bomb-lance. Gun: Barrel, socket, breech-snap, hinge, and lugs, gun-metal. Trigger, steel rod, projecting beyond the muzzle. Lance and cartridge combined. Harpoon: Common toggle-iron. The barbs on the toggle. Mortised head; rear end of shank made to fit the lugs of the gun. Eye for rope-strap. Toggle branded "J. A. S." (John A. Sawyer, manufacturer). Iron-strap, whale line; one end of strap bent into the eye of harpoon and the other provided with an eye-splice, into which one end of the whale line is intended to be fastened. Length of gun, $15 \frac{1}{2}$ inches. Length of trigger, 21 inches. Length of harpoon, 34 inches. Length of strap, 64 inches.

\section{Darting-gun:}

Breech, brass, cast with breech-piece. Barrel, steel, screwed to the breech-piece. Rear end of the gun terminates in a conical socket, into which may be fitted the pole or handle. A vertical slot is cut through the breech for the reception of the hammer, which was pivoted and retained in its firing position by the rod or trigger. Hammer, wanting. 'Trigger projects over the muzzle, and moves freely back and forth in a guide near the end of the barrel. A sleeve of metal, or other suitable material, was intended to fit over the breech, or lock-case, to render it water-tight.

The harpoon is of the pattern known as the "temple-gig." Toggle, malleable cast iron, pivoted in the cheelss of the forward end of the shank. Shauk, composed of two pieces of conjoined iron; first half, wrought iron, slotted near its rear end for the iron arm with rigid eye, to which the iron strap should be made fast, and provided with a female screw in a recess in the rear end; rear part of shank cast, and screwed to the

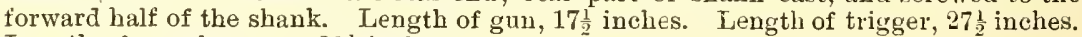
Length of gun-harpoon, $23 \frac{1}{4}$ inches.

\section{Bursted barrel of a whaleman's darting gun:}

Barrel of a darting gun, fractured by premature explosion of a bomb-lance when darted at a whale. Brought home by a whaleman as an interesting "curio." Portion of hickory pole in the socket. Length, 10 inches. 


\section{Improved breech-loading tonite hammerless darting-gun:}

This gun is an improvement over the old breech-loading darting-gun No. 2, manufactured by William Lewis, of New Bedford. It is $17 \frac{1}{2}$ inches long, seven-eighths of an inch bore, and is as light as is consistent with strength. It is loaded from the breech by unscrewing the barrel, and has been especially designed for Arctic whaling, but is equally effective in sperm whaling. The materials used are the same as in the old shoulder guns, but the lock case is entirely closed to prevent ice interfering with the action of the lock, and it will discharge the bomb under water as well as out without damage to any part of the gun.

\section{Freeman's bomb harpoon:}

An instrument with an explosive head for killing whales. Consists of a chambered head or magazine, which, when loaded, contains a charge fully equal to three-fourths of a pound of powder; a shank with a tubular head and two small rigid barbs, and socket for the pole. The inside mechanism consists of a time fuse, which extends from the shank into the magazine, a nipple for the percussion-cap, an actuating spring, and other appliances for releasing the cock, which are concealed in the recessed head of the shank. The trigger, or level-fluke, is fastened by a hinge-pin inmediately in rear of the lance-bomb. The action of the flesh as the instrument enters the whale presses down the trigger or fluke in a line with the shauk, and antomatically explodes and impels the head. Reloaded by substituting new heads. Length, $40 \frac{1}{2}$ inches.

\section{Pierce's darting-bomb:}

A kind of explosive lance known as the "darting-bomb." Used in connection with the darting-gun for killing whales. Patented and manufactured by Capt. Eben Pierce. Length, $15 \frac{1}{2}$ iuches.

\section{Mason's harpoon-bomb :}

Designed for improved swivel-gun. Consists of a point with three eutting edges, and cast-irou bomb, cast-iron shank with four parallel grooves on the sides, and au eye at the butt for the iron-strap. Two movable flukes are fastened with a set-screw to the forward end of the shank in rear of the bomb. Length, $31_{4}^{3}$ inches.

\section{Pierce's bomb-lance:}

A short explosive lance, with four small metal wings, which may be used in connection with the darting-gun when the latter is used as a shoulder-gun. Length, $15 \frac{1}{2}$ inches.

\section{Allen's bomb-lance:}

An example of the first patented bomb-lance used by American whalemen, for which letters-patent were granted Oliver Allen, Norwich, Conn., September 19, 1846. (United States Patent Office, No. 4764.) Rare. Familiarly kuown to the whalemen as the broom-stick lance. Length, 42 inches.

\section{Cunningham \& Cogan's bomb-lance:}

An improved bomb (with rubber feathers) and cartridge combined, used in connection with Cunningham \& Cogan's breech-loading gun and Cunningham's dartinggnu. Patented December 28, 1875. Length, $16 \frac{1}{4}$ iaches.

\section{Kelleher's hand bomb-lance:}

Consists of a lance-head, a tubular magazine, and the ordinary harpoon shauk, secured to a white-ash handle. A sliding clamp attached to a wire by impact explodes the bomb by means of a common frietion-primer, such as is used for discharging pieces of artillery. Socket served with marline to prevent iron-rust. Lance-strap spliced around the socket, seized to the handle in three places, and projecting through a hole at the butt. Length of lance and shank, $48 \frac{1}{4}$ inches. Length of pole, 70 inches.

\section{Brand's bomb-lance, No. 3 :}

Used in connection with Brand's No. 3 shoulder-gun. New model. Patented in 1879. Not much used at present. Length, 24 inches. 
Improved darting-gun, bomb-lance, and cartridge combined:

This lance is for seven-eighths of an inch bore and is constructed in the same manner as the shoulder-lance, except that it has no feather's, and loads, when using powder, from the end to which the cartridge is attached.

\section{Whaleman's hand-lance:}

A lance with a short wide blade, formerly used for killing whales. Superseded by the explosive lance. Length, 68 inches.

Whate hand-lance:

A lance formerly relied upon altogether for killing whales. Length, $5 \frac{1}{4}$ feet.

Whale hand-lance:

A nickel-plated hand-lance, used in giving the death wound. Length, $5 \frac{3}{4}$ feet.

Toggle iron.

Seal-lance:

Long head; diamond point; common shank and socket. Manufactured by James Barton for the New Loudon sealer's. New. Length, 321 inches.

\section{Seal-lance:}

A lance with a short shank, which may be used in killing seal, sea-elephant or walrus. Socket with an extended sleeve. Length, $28 \frac{1}{2}$ inches.

\section{Seal-lance:}

A lance for killing seal, sea-elephant, or walrus. Spoon-shaped head and extended sleeve or socket. Used by New Bedford sealers. Length, 24 inches.

\section{Grappling-iron :}

Used to catch the line thrown around the whale, also to anchor the boat to ice.

\section{Boat-spade:}

Used to cut hole in flukes where the line is made fast by which the whale is towed to the ship.

Cutting-spade: For cutting blubber from whale into pieces to mince.

Head-spade: Used to disjoint the head.

Throat-spade: Used to cut off the throat.

Boarding-knife: For boring hole in blubber and to make it fast for hoisting on ship. Mincing-knife: Used in mincing blubber to try out.

Pike: Used to pitch the blubber.

Gaff: For hauling the blubber.

Blubber-hook: Used to hoist blubber on deck.

\section{Applianoes for Strizing.}

Sword-fish harpoon.

Sword-fish lance.

Eel spears.

\section{Turtle-spear :}

The spear is attached to a pole 12 to 15 feet long, and is thrown into the back of the turtle, the fisherman being in a boat. The turtle is drawn in and secured by means of a line attached to the spear. By this method the turtle is badly injured, and often dies from the effects of the spear wound, and cannot be shipped long distances.

\section{Turtle-pegs :}

A small pointed piece of steel or brass, called a peg, is loosely fitted into a brass socket at the end of a 16-foot pole. Some pegs are 4-sided and others are rounded 
like the plug of a boy's top. A marline line is attached to the peg and runs to the hand of the fisherman. The peg is wedged into the socket by means of a bit of cotton cloth. When a turtle is seen in water up to 20 feet deep, the pole is hurled at it and the peg enters the back shell, and holds fast; the pole becomes detached and is subsequently picked up, and the turtle is hauled in by means of the line. The peg enters the shell one-half to 1 inch, and holds very securely, so that great force is sometimes necessary in order to extract it. The turtle is not serionsly injured and is available for distant shipment alive, the slight bleeding being controlled by a pledget of tobacco. Many tortoise-shell turtles, as well as green and loggerhead turtles, are taken in this way about the Florida keys and reefs.

\section{Hooks :}

Fishing Accessories.

Fish hooks of various kinds used in the mackerel fishery.

Fish hooks of various sizes and kinds used for general harbor fishing, such as cunner, flounder, ete.

Fish hooks nsed for pickerel fishing.

Fish hooks used in trawling for halibut.

Fish hooks: (1) For cod triawling. (2 and 3) Hardock trawling. (4,5 and 6) Cod hand-line fishing. (7 and 8) Pollock hand-line fishing. (9 and 10) Inshore trawling. Blue-fish hooks.

Mackerel jig.

Squid jig. The heaviest are used in tides; the lighter ones in slack water.

Blue-fish squids or hooks.

\section{Swivels :}

Snood swivels used on Georges Bank hand lines.

Lead-sinker swivels used in rip hand-line fishing.

Georges hawse swivels.

Line swivels for keeping the twist out of lines.

Patent snood swivels for Georges Bauk hand lines.

Swivel for rope hawse.

Line swivel.

"Pump" swivel, or improved snood swivel.

Improved hawse swivel.

Staff trawl buoy swivel.

Mooring.buoy swivel.

Brass haddock buoy swivels.

Improved purse-line swivel.

Trawl buoy swivels.

Halibut buoy swivel.

\section{Leads and sinker's:}

\section{Net sinker.}

Sinker for light lines in harbor fishing or shoal water.

Sinker for light lines in harbor fishing or shoal water.

Sinker for light lines in harbor fishing or shoal water.

Sinker for inshore hand line, old style.

Sinker for inshore hand line, old style.

Sinker, improved, for shore hand-line and pollock tishing.

Sinker, improved, for shore hand-line and pollock fishing.

Sinker, improved, for shore hand-line and pollock fishing.

Sinker, improved, for rip fishing.

Sinker, improved, for rip fishing and western bank fishing.

Sinker, improved, for Georges Bank drift fishing.

Sinker, improved, for rip fishing and western bank fishing.

Sinker, improved, for rip fishing.

Sinker, improved, for shore hand-line and pollock fishing.

Sinker, improved, for shore hand-line and pollock tishing.

Sinker, improved, for shore hand-line and pollock fishing.

Sinker, old style, for inshore hand-line fishing.

Sinker, old style, for inshore hand-line fishing.

Sinker, old style, for inshore hand-line fishing.

Sinker for light lines in harbor fishing.

Sinker for light lines in harbor fishing. 
Sinker for light lines in harbor fishing.

Net sinkers.

Net sinkers.

Sinker for light line harbor fishing, improved.

Sinker, old style, for shore hand-line fishing.

Sinker or lead, 9 pounds, for Georges Bank hand-line fishing.

siuker or lead, 8 pounds, for Georges Bank hand-line fishing.

Sounding lead, improved, having a metal fin to keep it from turning and twisting the line. The hole in the lower end, when sounding, is filled with soap to which the sand or mud at the bottom of the ocean adheres, showing the character of the bottow.

Old style sounding lead without the fin.

\section{Shore axd Vessel Accessories.}

Short-handled haddock or dory gaff. Long-handled Georges Bank gaff.

Mackerel gaff. Iron halibut hand gaff.

Three-tined fork. 'Two-tined fork. One-tined fork or pew.

Three-pronged ice chopper.

Mackerel bait mill.

Squilgee.

Gob stick and killer.

Hurdy-gurdy. This is attached to the dory and is used in the halibut fishery to haul up the halibut trawls.

Cockle hammer, for breaking cockles for bait in rip fishing.

salt scoop, used in salting fish of all kinds on the Grand Banks.

Ice scoop, nsed in the halibut fishery for icing halibut.

Wooden dory scoop.

Torch made of galvauized iron and used on the decks of fishing vessels while baiting up trawls and dressing fish at night.

Sticking-tommy, or candle holder: A candlestick in general use on fishing vessels which can be stuck on horizontal or perpendicular surfaces below decks.

Dummy roller : A trawl roller which is attached to the gunwale of the dory to haul trawls in shoal water.

Patent roller, used on the gunwale of the dories for hauling trawls in deep water.

Fishermen's woolen mittens, used in handling fish on the banks in winter.

Cotton mittens, used in gibbing mackerel and in general where woolen mittens would be too warm.

Small woolen nipper's, used for hand-line or single-dory fishing on the inshore grounds.

Large nippers, used for hand-line fishing on Georges Bank, haddock trawling, etc. Rubber nippers, used for shore fishing, haud lines, etc.

Kubber bauds, used for holding on mittens.

Rubber bauds, used for holding the oil clothes close around the rubber boot.

Mackerel bait heaver, used for throwing bait or "chum" to toll mackerel alongside the vessels.

Soapstone boot drier, used for drying rubber boots on fishing vessels. The soapstone is heated and placed in the boot over night.

Files used for sharpening fish hooks.

Rubber finger cot used to protect the finger when cut or injured.

Tin horn used in dory in foggy weather.

Oak mallet used in the halibut fishery for pounding ice; it is preferred to anything else as the ice is pounded to almost the consistency of snow and keeps the fish in better condition than coarse ice.

Oak scrub broom, in general use on fishing vessels for scrubbing dories, decks, pens, etc., to remove blood, scales, etc., after dressing fish.

Seine needle, used for mending seines.

Sailors' palm, used for mending sails.

Curry-comb, used in fish houses and markets for scaling and cleaning fish.

Mackerel jig mold, with hook in position.

Splicer, used in making cod trawls and small lines.

Splicer, used in making halibut trawls.

Mackerel, bait mill.

Mackerel plow or reamer, used for cutting two gashes in a split fish to give it the appearance of being fatter than it really is.

Halibut heading knife, used in fish-houses for cutting off the heads of halibut and large cod.

Halibut fletching knife, used for cutting from the bone the flesh which is to be salted and smoked. 
Common bait knife, used for cutting up bait for eod, haddock, and other fishes.

Bait chopper, used in halibut fishery for chopping bait.

Haddock rippers, used for ripping open haddock.

Clam knife, used for opening clams for bait.

Mackerel splitting knife.

Knife, used in fish lofts for skinning dry fish.

Hook, used in skinning loits for removing the nape bone.

Knife, used for throating cod and other large fish.

Knife, used for splitting round fresh cod in preparing them for salting.

Knife, used in halibut fishery to remove flesh and blood from the backbone after cutting.

Oyster hardie: Types Nos. 1 and 2, made of irou, are in common use in oyster houses in Philadelphia, New York, and Baltimore. Type No. 3 is known as the Philadelphia pattern.

Bleak hammer used in oyster houses in connection with the hardie for breaking ofi the end of the oyster shell.

Pliers, used for opening fresh-water mussels in order to remove the pearls.

Knife, used for opening and removing pearls from fresh-water mussels.

Clam knife.

Clam tongs.

Culling hammers; representing the various types used for culling oysters on board vessels and in oyster houses.

Oyster knives:

Type used in Providence, R. I.

Hook blade, type used in Norfolk, Va.

Straight blade, used in Alexandria, $\mathrm{Va}$.

New York patterns Nos. 1, 2, 3, 4, 5 .

Sampler's knife, plain blade.

Used in Gulf Coast States.

Used in New Haven, Conn.

Photographs of Fishery Scenes, eto.

225 photographs illustrating all leading fisheries of coast and interior waters.

\section{Mutascope Pictures of Fishing Scenes.}

Lifting a shad pound-net, Albemarle Sound, N. C.

Landing a shad seine, Albemarle Sound, N. C.

Boating a shad seine, Albemarle Sound, N. C.

Lifting a lobster pot, Kittery Point, Me.

Catching cod, Kittery Point, Me.

Unloading a cod vessel, T-wharf, Boston, Mass.

Unloading a halibut vessel, Gloucester, Mass.

View of Fulton Fish Market, New York, on a busy day.

Capt. Paul Boynton feeding sea-lions, Coney Island, N. Y.

Catching, preparing, and canning salmon on Columbia river near Astoria, Oregon (9 reels).

\section{Statistical Chart of United States Fisheries.}

Chart showing by States the persons employed, apparatus used, capital invested, and value of the commercial fisheries of the United States, based on data collected by the United States Fish Commission.

\section{Apparatus Used in Angling.}

\section{Tackle for black bass fly fishing:}

Lancewood rod.

Click reel, capacity 30 yards.

Waterproof line.

Leaders.

Casting spoons, assorted.

Brass or copper leader box, with felt. 
Fly book.

Casting flies.

Floating bait pail, 12-quart capacity.

Creel, capacity 25 pounds.

Tackle for black bass and pike perch fishing:

Steel rod $8 \frac{1}{2}$ feet long, weight 10 ounces, for black bass and pike perch.

Split bamboo rod $9 \frac{1}{2}$ feot long, for black bass and pike perch.

Bristol steel rod, for pike perch, pike, and muskellunge.

Black bass reel, quadruple, back-sliding click, front-sliding drag.

Black bass reel, adjustable click, protected balance handle.

Black bass line, silk, enamel finish, 50 yards.

Black bass fly line, braided silk, 25 yards.

Assorted tront flies with helpers, used for black bass and pike perch.

Black bass hooks, snelled, double gut.

Black bass leaders.

Black bass spoons, assorted.

"Phantom" minnow for black bass and pike perch.

Black bass swivels.

Cork floats for black bass and pike perch.

Leader case with felts.

Black bass fly book, four pockets, holding $3 \frac{1}{2}$ dozen.

Floating bait pail, eapacity 12 quarts, for black bass.

Minnow trap, for black bass and pike perch fishing.

Landing net, for black bass and pike perch.

Ring sinkers, for black bass and pike perch.

Minnow seine, for catching bait for black bass.

Tackle for black bass fishing with short frog and lure casting rod:

Split bamboo rod 6 feet long, weight 6 ounces, for casting minnows, frogs, and artificial flies.

Reel and line, quadruple, multiplying, adjustable click and drag, 100 yards.

Hooks.

Frog gang.

Two-hook minnow gang.

Artificial frog.

"Manco" lure 102.

"Manco" lure 104.

"Yellow kid" surface troll.

Floating perch.

Sinking perch.

Casting devon.

\section{Tackle for trolling for black bass and large trout:}

Henshall black bass rod, split bamboo.

Split bamboo rod $7 \frac{1}{4}$ feet long; weight, 16 ounces.

Multiplying black bass reel, for trolling.

Silk black bass line for trolling, 50 yards.

Minnows for black bass trolling.

Minnow gangs for black bass trolling.

"Indian Rock" spinner for black bass trolling.

Black bass spoons, assorted.

Belgrade spinner, for black bass trolling.

\section{Tackle for rock bass and crappie fishing :}

Rod $8 \frac{1}{2}$ feet long, for rock bass and crappie.

Rock bass reel, quadruple, multiplying, back-sliding click, front-sliding drag.

Rock bass line, enamel waterproof silk, 50 yards.

Rock bass leaders, double gut.

Rock bass flies, double gut; sproat hook.

Rock bass hooks, double gut.

Bait box.

Adjustable float, Bristol patent, for rock bass fishing.

Adjustable sinkers, for rock bass fishing.

Box swivels, for rock bass fishing. 
Tackle for trout bait fishing:

Trout bait rod, split bamboo, $9 \frac{1}{2}$ feet long, for striped bass and bait fishing.

Trout bait, reel and line; multiplying reel, adjustable click.

Tront bait box, "Crescent."

Trout bait hooks.

Tackle for trout and grayling fly fishing:

Split bamboo fly rod, for trout and grayling.

Antomatic trout reel, capacity 50 yards.

Waterproof trout line, braided silk.

Leaders, assorted styles.

Trout fly book.

Trout flies, styles for general use.

Trout flies, special styles for stream fishing.

Trout flies, cork body flies of special lightness.

Midge dry trout flies, eyed hooks.

Eyed-hook trout flies.

Box for eyed trout flies.

Trout creel, capacity 12 pounds.

Tront basket sling.

Trout landing net.

Releaser, for cutting twigs from tangled lines and flies.

Tackle for striped bass (large fish) fishing:

Greenheart rod 7 feet long, weight 16 ounces.

Chum rod, natural bamboo.

Light rod, split bamboo, for estuary fishing.

"Vjetory" reel, multiplying, back-sliding click, 200 yards.

Linen line, 100 yards.

Hooks.

Swivels.

Pyramid sinkers.

Twisted gut leaders, 4-ply, 4 lengths.

Automatic gaff.

Finger stalls.

Hall combination minnow bucket, for keeping minnows and frogs alive.

Tackle for salmon fishing:

Split bamboo rod for fly-fishing.

Flies.

Rad belt.

Gaff hook.

Fly book, 5 leaves, 80 hooks.

Brass or copper leader box, with felt.

Tapered leaders, $4 \frac{1}{2}$ feet braided, $4 \frac{1}{2}$ double gut.

Braided silk line, tapered, 60 yards.

Reel with click and adjustable drag, $4 \frac{1}{2}$ inches, 300 yards.

Tackle for tarpon and other heavy fishing:

Greenheart rod 7 feet long, weight 12 ounces, for tarpon, tuna and other salt-water angling.

Tarpon reel, with patent handle drag.

Tarpon line, 600 feet.

"Captiva" tarpon hooks (large).

"Captiva" tarpon hooks (small).

Tarpon hooks on wire, assorted.

Tarpon swivels, assorted.

Tarpon casting sinkers, assorted.

'Tarpon pyramid sinkers, assorted.

Tarpon egg sinkers, assorted.

Thumb stalls, for tarpon fishing.

Gaff hooks, for tarpon fishing.

Rod-butt rest, for tarpon fishing.

Tarpon squids.

Tarpon squids, for casting. 


\section{Steel fishing rods:}

Rod 10 feet long, weighing 10 ounces. For bass and river fishing; also used in Rocky Monntain and Pacific coast fishing.

Rod 10 feet long, weighing $10 \frac{1}{2}$ ounces. For bass and boat-fishing, and general fishing where a long rod is required.

Rod 10 feet long, weighing $9 \frac{1}{2}$ ounces. For trout fishing.

"Henshall" bass rod. Length, $8 \frac{1}{2}$ feet; weight, 10 ounces. For bass and heavy bait fishing.

"St. Lawrence" bass rod. Length, $7 \frac{1}{2}$ feet; weight, 8 onnces. For bass, pickerel, muskellunge, and general bait fishing.

Fly rod. Length, 8 feet 7 inches; weight. $7 \frac{1}{2}$ ounces. For light fly fishing.

"Expert" bait casting rod. Length, $6 \frac{1}{2}$ feet; weight, $8 \frac{1}{4}$ ounces. A short rod for bait casting, etr.

"Rangely" fly rod for trout fishing. Length, 9 feet; weight, $8 \frac{1}{4}$ ounces.

"Farorite" bait casting rod. Length, 7 feet; weight, $8 \frac{3}{4}$ ounces.

"Western" bait casting rod. Length, 6 feet; weight, $8 \frac{1}{4}$ ounces. For bait easting and general boat fishing.

Bass rod. Length, $5 \frac{1}{2}$ feet; weight, 8 onnces. For bait casting and general boat fishing.

Bait rod. Length, 5 feet; weight, 8 ounces. For bait casting and general boat fishing.

"Muskellunge" rod. Length, $7 \frac{1}{2}$ feet; weight, 13 ounces. For muskellunge and surf fishing.

"Trunk" rod. Length, 9 feet; weight, $8 \frac{1}{2}$ ounces. For trout fishing.

"Kalamazoo" bait casting rod. Length, $5,5 \frac{1}{2}$, and 6 feet; weight, 8 to $8 \frac{1}{2}$ ounces. For bait casting exclusively.

\section{Mutascope Pictures of Angling Scenes.}

Angling for large month black bass, Occoquan, Vir.

Angling for black bass, Muskoka Lakes, Ontario.

\section{OBJECTS AND PRODUCTS OF THE FISHERIES.}

Fishes.

stuffed and painted skins of fishes:

Food tishes of Atlantic coast.

Food fishes of Pacific coast.

Food fishes of Great Lakes.

Food fishes of interior waters.

Illustrations of food fishes:

Hawaiian Islands.

Porto Rico.

Reptiles.

5 specimens diamond-back terrapin (Malaclemmys), common in salt marshes along the coast from Massachusetts to Texas.

1 specimen soft-shelled tortoise, species of which are found generally throughout the United States east of the Rocky Mountains.

5 specimens fresh-water terrapins or sliders, foumd in many parts of the United States.

6 specimens pond and wood tortoises, common generally in the United States.

Econonic Crustacea of the United States and Porto Rico.

Pacific edible crab (Cancer magister). Pacific coast. Used as food.

Alaska spider crab (Lithodes kamschatkis). Northern Pacific Ocean. Used as food. Lopholithodes mandtii. Pacific coast. Used as food.

Scyllarides requinoctiaiis. Porto Rico and West Indies. Used as food.

Deep-sea crab (Geryon quinquedens). Eastern coast of United States: 500 to 1,000 fathoms.

Stone crab (Menippe mercenaria). South Atlantic and Gulf coasts. Used as food. Common edible crab; blue crab (Callinectes sapidus). Atlantic coast. Important as food.

Spider crab (Lithodes maia). North Atlantic coast.

Lophoiithodes foraminatus. Atlantic coast. Used as food. 
Kelp crab (Epialtus productus). British Columbia to southern Califorvia.

Horseshoe crab, king crab (Limulus polyphemus). Atlantic coast. Used as fertilizer and as food for swine. This has a limited use as food for man.

Lady crab (Ovalipes ocellata). Atlantic coast. Used as bait.

Sand crab (Ocypode albicans). Long Island to Brazil. Used as bait.

Rock crab (Cancer irroratus). Labrador to South Carolina. Used as bait and occasionally as food.

Jonah crab (Cancer borealis). Nova Scotia to New York. Used as bait and occasionally as food.

Mud crab (C'arcinides menas). Atlantic coast. Occasionally used as bait.

Oyster crab (Pinnotheres ostreum). Atlantic coast. Considered a delicacy as food.

Mithrax hispidus. Gulf coast.

Spider crab (Libinia enarginata). Atlantic coast.

Box crab (Calappa, flammea). Porto Rico. Used as foud.

Portunis spinimanus. Porto Pico. Used as food.

River sbrimp; "Camarone" (Bithynis jamaicensis). Southern United States and

Porto Rico. Used as food.

Carpilus corallinus. Porto Rico. Used as food.

Terrestrial hermit crab (Conobitr diogenes). Porto Rico. Used as food.

Hermit crab (Petrochirus bahamensis). Porto Rico. Used as food.

Land crab; "Juey" (Cardisoma guanhumi). Porto Rico. TIsed as food.

Coral crab' (Grapsus grapsu:). P(orto Rico. Used as food.

Edible crab (Callinectes bocourti). Porto lico. Used as food.

Hermit crab (Pagurias insignis). Porto Rico. Used as food.

Rock crab (Cancer antennarius). Pacific coast. Used as food.

River crab; "Boragina" (Epilobocera sinurtifrons). Porto Rico. Used as food.

Mangrove crab (Goniopsis cruentata). Porto Rico. Used as food.

Edible crab (Callinectes dance). Porto Rico. Used as food.

Land crab (Gecarcinus lateralis). Porto lico. Used as food.

Land crab (Ucides cordatus). Porto Rico. Used as food.

Hippa (Emerita talpoida). Atlantic coast. Used as bait.

Mintis shrimp (Chloridelia empusa). Atlantic coast.

Pacific prawn (Pandulus dance). Pacific coast. Used as food.

Red crab (Cancer productus). Pacific coast. Used as food.

Spiny lobster (Palinurus interruptus). Pacific coast. Used as food.

River shrimp; "Camarone" (Bithynis acanthurus). Porto Rico. Used as food.

Pacific coast stirimp (Crangon franciscorum). Used as food.

Southeru shrimp; "Camarone marina" (Penaus örasiliensis). Gulf coast and Porto

Rico. Important as food.

Crawfish; Crayfish (Cambaris affinis). Freshwaters of eastern United States. Used as food.

Crawfish on nest or turret.

American lobster. Giant specimen. Weight $23 \frac{1}{2}$ pounds.

Spiny lobster (Panulirus argus). Florida. Used as food and bait.

Economic Mollusca of the United States.

Eastern oyster (Ostrea virginica).

Pacific oyster (Ostrea lurida).

Flat razor-shell clam (Siliqua patula). Alaska to California. Used as food.

Razor-shell clam (Ensis directus). Atlantic coast. Used as bait.

Long clam, soft clam (Mya arenaria). Atlantic coast south to South Carolina.

Used as food and bait.

Platyodon cancellatus. California.

Hen clam, surf clam (Spisula similis). Southeast coast United States. Used as food and bait.

Hen clam, surf clam (Spisula solidissima). Atlantic coast. Used as food and bait. Alaska surf clam (Spisula planulata). Alaska.

Cuneate clam (Grathodon cuneatus). Gulf coast of United States. Used as food. Giant clam (Tresus nuttalli). Pacific coast. Used as food.

Donax lavigata. Pacific coast. Used in the mannfacture of clam juice.

Round clam (Saxidomus aratus). California. Used as food.

Round clam (Saxidomus nuttalli). California. Used as food.

Hard clam; quabog (Venus mercenaria). Atlantic coast. Used as food and bait.

Florida quahog (Venus mortoni). Florida. Used as food and bait.

Hard clam (Venus simillima). California.

Meretrix nimbosa. Florida.

Tivela crassateloides. California. 
California Itttle-neck clam (Tapes staminea). California.

Deep-water clam (Cyprina islandica). Atlantic coast south of New York. Occasionally used as food and bait.

California cockle (Cardium corbis). Pacific coast.

Florida cockle (Cardium robustum). Florida.

Bloody clam (Area nexata). Massachusetts to Mexico. Oecasionally used as bait. Common mussel (Mytilus edulis). Atlantic, Gulf, and Pacific coasts and Europe.

Used as food and bait.

California mussel (Mytilus californicus). Pucific coast. Used as food.

Horse mussel (Modiolus modiolus). Pacific coast, Atlantic coast south to New Jersey,

Europe. Used as fond and bait.

Ribbed mussel (Modiolus plieatulus). Maine to Georgia. Used as food and bait.

Giant scallop (Pecten magellanicus). Labrador to New Jersey. Used as food.

Pacific coast scallop (Pecten caurinus). Pacific coast. Used as food.

Common scallop (Pecten irradians). Atlantic coast.

Scallop (Pecten ventricosus). Pacific coast.

Rock oyster (Hinnites giganteus). California.

\section{Eastern Oysters from Princtpal Beds of Atrantic and Pactfic Coasts.}

\section{Hyannis, Mass.}

Providence River, Rhode Island.

Greenwich, Conn. Old oyster from natural beds.

Greenwich, Conn. Old oyster from planted beds.

Shinnecock Bay, Long Island.

Blue Point, Long Island.

Saddle Rock, Long Island.

Rockaway, Long Island.

Tangier Sound, Maryland.

Chincoteague, Va. Some of the valves show inclusions of mud between layers of the shell.

York River, Va.

James River, Va.

Lynnhaven Bay, Va. Large specimen, showing inclusion of mud between layers of shell near the tip.

Beaufort, S. C. Cluster of young on old raccoon oyster.

Beaufort, S. C. Cluster of raccoon oysters from muddy tide floats.

Beaufort, S. C. Single oysters separated from clusters when young, showing great improvement in shape over raccoon oysters.

Charleston, S. C. Planted oysters.

Troup Creek, Ga.

St. Georges Sound, Fla.

St. Andrews Bay, Fla.

A palachicola Bay, Fla.

Silvias Bar, St. Georges Sound, Fla. Shows seaweed adherent to ralves, characteristic of these beds.

Mobile Bay, Ala.

Mobile Bay, Ala. Large specimen.

Bay Jump, La. The thick shells are characteristic of these beds.

Jack Stout Bayou, La.

Cedar Bayou, Tex. "Texas saddleroeks."

San Francisco Bay, Cal. Eastern oysters transplanted from Atlantic coast when small.

San Francisco Bay, Cal. Eastern oysters. The offspring of transplanted stock.

Yaquina Bay, Oreg. Eastern oysters transplauted from Atlantic coast when small.

\section{SPoNGes.}

Of the fishery products not used for food the sponges rank among the most important, being extensively employed for various purposes in all civilized and many barbarous countries. Florida is the only State on whose shores commercial sponges are found. They are there taken in water ranging from a few feet to 50 feet in depth, and occur in abundance throughout the Florida reefs and keys and on the western coast as far north as St. Marks. The annual value of the Florida sponge fishery is from $\$ 500,000$ to $\$ 600,000$, representing upward of 400,000 pounds of dry sponges.

When first taken from the water the meshes of the sponges are filled with a pulpy mass, aud the external surface is covered with a skin perforated for the currents of 
water, on which the animal depends for its food and growth. Several natural sponges are shown, preser'ved in alcohol.

The kinds of sponges recognized in the local sponge fishery and trade are sheepswool, yellow, velvet, grass, and glove. The sheepswool. which is found among the Florida Keys and in the Gulf of Mexico, is the best grade of sponge, exceeding in value all others combined. It is used for a great variety of domestic and other purposes, and is the leading bath and toilet sponge. 'The average wholesale price per pound received by the fishermen is $\$ 2.50$ to $\$ 2.75$. The yellow sponge, of which the most valuable grade comes from the Florida Keys, ranks next to the sheepswool in commercial importance. The average wholesale price is 60 cents to $\$ 1$ per pound. It is widely used for household purposes, and by painters, calciminers, wood workers and others for polishing and scraping. The velvet or boat sponge is of superior grade, with a very soft texture, and is employed for the same purposes as the sheepswool. It is not abundant, and brings abont $\$ 1.25$ a pound. The grass and glove sponges are very abundant, but, being of inferior quality, they are only sparingly used for the toilet. 'They are, however, extensively employed in livery stables, for applying enamel and stiffening to fabrics, for absorbing oil in condensing tanks, and for many other purposes. The glove sponges are worth only 15 cents a pound, and the grass 30 or 35 cents, wholesale.

The artificial bleaching of sponges is a common practice and improves their appearance, but unless very judiciously done is likely to impair their durability. Bleached sponges of all the standard grades are exhibited in the collection.

\section{Sheepsroool sponges from Gulf of Mexico:}

The sheepswool is the best grade of sponge, and exceeds in value all otler kinds combined. The best quality comes from the grounds off the northern part of the west coast of Florida. The present average wholesale price to the fishermen is about $\$ 2.75$ per pound. This is the leading toilet sponge, and is also employed for many other domestic and special purposes.

\section{Sheepsioool sponges from Florida Keys :}

The present average wholesale price received by the fishermen is $\$ 2.50$ per pound. This sponge is extensively used for a great variety of domestic and other purposes, and is the leading bath sponge.

\section{Velvet or boat sponges from Florida Feys :}

A superior grade of sponge, with very soft texture. Valued at about \$1.25 per pound, wholesale, at the local sponge markets. Used for toilet and other domestic purposes.

\section{Tellow sponges from Florida Keys:}

A valuable species, much used for domestic purposes and by woodworkers, painters. and other artisans. The average wholesale price when first landed from the sponge grounds is $\$ 1$ per pound. The yellow sponges from the Florida Keys are superior to those from grounds in the Gulf of Mexico.

\section{Fellow sponges from Gulf of Mexico:}

Somewhat less valuable than the same species from the Florida Keys. The average wholesale price is about 60 cents per pound to the fishermen.

\section{Grass sponges from Gulf of Mexico:}

A cheap sponge, reaching a large size, and growing in great abundance on parts of the Gulf coast; it is used for the toilet and for numerous domestic and other purposes. The average wholesale selling price to the fishermen is 35 cents per pound.

\section{Grass sponges from Florida Keys :}

This is a cheap grade of sponge growing in great abundance in Florida waters. It is sparingly used for the toilet, and is also employed in livery stables, in condensingtanks to take up oil, for applying enamel and stiffening to fabrics, and for a large variety of other purposes. Average wholesale price to fishermen, 30 cents per pound.

\section{Glove sponges from Florida Keys :}

The cheapest grade of commercial sponge, valued at only 15 cents a pound wholesale. It has a limited use for domestic and other purposes.

\section{Wire or bastard sheepsoool sponges from Florida Keys:}

A very coarse, stiff sponge of little commercial value and very limited usefuluess. 
Sheepsioool sponges, artificially bleached.

Yellow sponges of various kinds, artificially bleached.

Velvet or boat sponges, artificially bleached.

key grass sponges, artificially bleached.

Rock Island grass sponges, artificially bleached.

Glove sponges, artificially bleached.

Sponge clippings :

Waste material from the trimming of sponges, which can be obtained in considerable quantities at a small price. The discovery of a nse which will establish a market. for this is desirable.

Sheepsioool sponges: Baled for the market.

Yellow sponges: Baled for the market.

Grass sponges: baled for the market.

Bleached sheepsroool sponges: Baled for the market.

\section{Products of the Fisheries.}

Preserved by canning, salting, pickling and smoking:

Anchovies prepared in brine.

Brook tront canned in oil.

Clams canned fresh.

Clam chowder, soup, juice, canned.

Cod salted in various forms.

Cod sounds and tongues, pickled.

Crabs, deviled and fresh, canned.

Crab meat, canned.

Eels, pickled and smoked.

Finnan haddie (haddock), smoked.

Halibrat, salted and smoked.

Herring (boned), smoked and piekled.

Lobster, canned fresh.

Mackerel, soused, and canned fresh and with sauces.

Oysters, canned fresh.

Salmon, canned fresh.

Sardines, canned in oil, with mustard and with sauces, and soused.

Shrimp, pickled, deviled and fresh.

Terrapin soup, canned.

Turtle meat, canned fresh.

Turtle soup, canned.

\section{Used for clothing (furs):}

Seal skin, head natural, center plucked, rump dyed.

Newfoundland hair seal, natural.

Newfoundland hair seal, dyed.

Wool seal, natural.

Wool seal, dyed.

Beaver, natural.

Beaver, plucked.

Beaver, plucked and dyed.

Hudson Bay otter, natural.

Hudson Bay otter, plucked.

Hudson Bay otter, plucked and dyed.

Alaska seal skin, dyed.

Mink skin, natural.

Muskrat skin, natural.

Nutria skin, plucked.

Sample of sea otter skin. 


\section{Leathers:}

8 alligator skins, tanned and dyed.

1 alligator claw, tanned.

1 beaver tail, tanned.

1 beaver skin, tanned.

2 crocodile skins, tanned and dyed.

2 dog-fish skins.

2 eel skins, tanned.

1 frog skin, tanned.

2 gar skius.

Sample manatee leather.

Sample porpoise leather.

1 porpoise skin, tanned.

1 ray skin.

3 seal skins, tanned and dyed.

1 seal skin, tanned, split, and grained.

12 samples seal leather, dyed.

6 samples sea lion leather, dyed.

1 sea lion skin, tanned.

2 sturgeon skins.

1 white whale skin, tanned.

2 wolf-fish skins, tanned.

Sample whale leather.

1 sample walrus leather, dyed.

Ivory, bone, and shell:

2 narwhal tusks.

7 walrus tusks.

8 sperm whale tusks.

Sperm whale with teeth, lower jaw of.

15 alligator teeth.

2 slabs whalebone, bowhead (best quality), Arctic Ocean.

3 slabs whalebone, bowhead (cullings), Arctic Ocean.

3 slabs whalebone, bowhead, from northern Pacific Ocean.

Baleen from mouth of finback whale.

2 hawksbill turtles stuffed, polished shell.

9 upper and lower plates hawksbill, rough and polished.

3 upper plates South Pacitic tortoise, partly polished.

Loggerhead turtle shell.

Green turtle, stuffed.

Green turtle shell.

Tortoise shell, Philippine Islands.

\section{Fertilizer's :}

15 specimens of fertilizer's prepared for special purposes from the waste of glue factories.

4 specimens of fertilizers made from fish waste and offal.

2 specimens of menhaden fish scrap.

Lake-fish scrap.

Herring guano.

Salmon guano.

King-crab meal.

Ground mussel shells.

Shrimp skin dried for fertilizer by Chinese in California.

\section{Oils and fats :}

Blackfish, natural.

Blackfish, bleached.

Blackfish, body.

Blacktish, head, extra refined, for watches, clocks, chronometers.

Blackfish, melon, extra refined, for watches, clocks, chronometers.

Cod-liver, medicinal.

Cod-liver, crude, Beriug Sea.

Cod.

Cod, medicinal, crude. 
Cod, medicinal, refined.

Cramp-fish liver.

Dog-fish liver.

Herring, cold pressed.

Herring, crude.

Herring, refined.

Lake fish, refined.

Lake fish, crude.

Menhaden, bleached.

Menhaden, extra refined.

Menhaden, pressed.

Menhaden, Chesapeake Bay, 3 grades.

Ocean sunfish.

Porpoise body.

Porpoise, natural.

Porpoise, bleached.

Porpoise, jaw, extra refined, for watches, clocks, chronometers.

Puffing pig, or harbor porpoise.

Puffing pig, refined.

Sea elephant, natural.

Sea elephant, strained.

Seal.

Shark.

Sperm, bleached, winter.

Sperm, bleached, winter, extra.

Sperm, natural.

Sperm, refined.

Sturgeon.

Sword-fish.

Walrus.

Whale, natural, winter.

Whale, bleached, winter.

Whale, Arctic bowhead.

Whale, refined.

Spermacetti, crude.

Spermacetti, refined.

Whale oil pressings.

Whale oil soap.

Whale oil, stearine.

\section{Glues and isinglass:}

14 specimens of liquid fish glue made from cod and cusk skins, prepared for special purposes, as follows: Engraving on zinc and copper, leather belting, glueing sheet metal to wood, printing and book-binding, envelope making, manufacture of fine woolen goods, sizing white straw hats, shoe manufacturing, adhesive plasters, manufacture of gummed papers, car building and piano work, and for labeling bottles.

6 specimens liquid fish glue made from fish skins and heads, for general use.

Sheet glue made from haddock and pollock skins.

Sheet glue and gelatine made from lake fishes.

Cod, cusk and haddock skins dried, from which the better qualities of glue are made.

Ribbon isinglass.

Air bladders or sounds of fishes from which isinglass is manufactured: Rio Grande. hake, weak-fish, Maracaibo, Bombay, Russian, South American corbria, Persian leaf, and Norway cod.

Pearls and nacre:

22 pearls from fresh-water mussels from Mississippi River and its tributaries.

57 baroque pearls from same mussels.

100 pearly formations from fresh-water mussel (Unio complanatus) from Maryland.

105 valves of fresh-water pearl-bearing mussels from Mississippi Basin, polished to show nacre or mother-of-pearl.

14 valves of fresh-water pearl-bearing mussels from Mississippi Basin, showing formation of pearls and irregular pearly formations. (Lampsilis rectus, L. ligamentinus, Quadrula ebena, Q. undulata).

32 specimens of pearl-bearing fresh-water mussels, showing different colored nacre, as follows : 
Lampsilis alatus.

Lampsilis rectus.

Lampsilis fallaciosus.

Lampsilis ligamentinus.

Symphynota complanata.

Symphynota costata.

Unio crassidens.

Unio gibbosus.

Anodonta footiana.

Quadrula tuberculata.

Quadrula ebena.

Quadrula pustulosa.

Quadrula heros.

Anodonta grandis.

Senweeds useful for food, fertilizers, etc.:

Ulva, "sen lettuce," used for fertilizer.

Chondrus crispus, "Irish moss," used for jellies.

Laminaria. "kelp," used for fertilizer and for making iodine.

Fucus, "rock weed," used for fertilizer and food.

Rhodymenia palmata, "dulse," used for food.

Sargassum. "gnlf-weed," used for fertilizer and making iodine.

Porphyra, "laver," used for food by Chinese.

Phyllitis, used for fertilizer.

Irish moss, prepared for market.

Dulse, prepared for market.

Sundry products:

Dessicated fish from fresh cod heads, for poultry food.

Crushed mussel shells for poultry food.

Cuttle-fish bone with die cut for molding rings, medals, etc.

Dried sbrimp prepared for food by Chinese in California.

Dried abalone meat prepared for food by Chinese in California.

Dried cuttle-fish prepared for food by Chinese in California.

Dried squid prepared for food by Chinese in California.

Dried spinal cord of sturgeon prepared for soups by Chinese on the west coast.

\section{Salt Used for Curing Fish.}

Trapani, used in New England for curing cod, hake, haddock, pollock, cusk, aud halibut. Obtained from Sicily.

Liverpool, used in New England for curing mackerel and herring. Obtained from Liverpool.

Turks Island, used in fisheries of Potomac and other rivers.

Saginaw, used in fisheries of Great Lakes.

Marine City, used in fisheries of Great Lakes.

Luneburg, used in pleparing caviar.

Bay salt, used on Pacific coast and Alaska.

\section{Manufacture of Pearl Buttons and Ornaments from Marine Shells.}

4 pearl-oyster shells, Meleagrina margaritifera, natural.

Black mother-of-pearl shell, Meleagrina nigromarginata, natural.

Turbo marmoratus, natural.

Japan shell (Haliotis), natural.

Red abalone shell (Haliotis), natural.

Blue abalone shell (Hatiotis), natural.

Green abalone shell (Haliotis), natural.

Florida conch (Strombas gigas), natural.

4 valves Japanese pearl oyster, showing growth of artificial pearls.

1 each of Turbo, pearl oyster, black mother-of-pearl shell, and abalone, ground and polished.

13 of above shells showing process of manufacturing buttons.

Pearl oyster and abalone shells marked to show how they are utilized in manu. facturing.

Mother-of-pearl slabs cut and ground for inlaying.

Abalone slabs cut and ground for lacquer work.

Samples of buttons.

Samples of ornaments. 


\section{Mussey Fishery and Peari-button Industry of the Mississippi Vallex.}

Specimens of pearl-bearing fresh-water mussels from Mississippi River which are chiefly used in manufacturing buttons, as follows:

"Niggerhead" (Quadrula ebena).

"Blue-Point" (Quadrula undulata).

"Yellow sand-shell " or " yellow back" (Lampsilis anodontoides).

"Black sand-shell" (Lampsilis rectus).

"Slough sand-shell" (Lampsilis fallaciosus).

"Mucket" or " mouket" (Lampsilis ligamentinus).

"Pocketbook" (Lampsilis capax).

"Pocketbook" (Lampsilis ventricosus).

"Deerborn" or "buckhorn" ( Tritigonia tuberculata).

"Butterfly" (Plagiola securis).

"Hatchet back" or "hackle back" (Symphynota complanata).

"Warty back" (Quadrula pustulosa).

Mussel shells, distorted. Six valves mussel shells, injured.

Manufacture of buttons :

18 shells from which blanks have been marked and cut.

Blanks, rough, ground, faced, shaped, drilled, and polished.

Finished buttons.

Photographs illustrating button manufacturing, and apparatus and methods of fishing for fresh-water mussels.

\section{THE AQUARIUM.}

The purpose of the aquarium is to show (1) all the fresh-water and salt-water fishes propagated and distributed by the Commission; (2) all other important fishes and other water animals of the interior, Great Lakes, and both Atlantic and Pacific coasts which it may be possible to obtain and transport; and (3) ornamental and curious species of fishes and invertebrates of our fresh waters and coasts. The number of different kinds of animals on exhibition at any one tıme is upwards of 100, and may at times reach 150 . The species are constantly changed, however, by the arrival of fresh lots from all sections, mostly brought in the special railway cars of the Commission. The central pool contains seals, sturgeon, large cat-fish, and various kinds of turtles. 





\section{LIBRARY OF CONGRESS}

'IIIIII

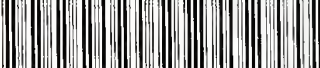

$0002877123 \mathrm{~A}$ 